\title{
Hydrogeological and Hydrochemical Assessment of Basin Granitoids in Assin and Breman Districts of Ghana
}

\author{
Asare Asante-Annor, Joseph Acquah, Ebenezer Ansah \\ Geological Engineering Department, University of Mines and Technology, Tarkwa, Ghana \\ Email: aasante-annor@umat.edu.gh
}

How to cite this paper: Asante-Annor, A., Acquah, J. and Ansah, E. (2018) Hydrogeological and Hydrochemical Assessment of Basin Granitoids in Assin and Breman Districts of Ghana. Journal of Geoscience and Environment Protection, 6, 31-57. https://doi.org/10.4236/gep.2018.69004

Received: July 31, 2018

Accepted: August 31, 2018

Published: September 3, 2018

Copyright () 2018 by authors and Scientific Research Publishing Inc. This work is licensed under the Creative Commons Attribution International License (CC BY 4.0).

http://creativecommons.org/licenses/by/4.0/

\begin{abstract}
Hydrogeological and hydrochemical assessments were carried out in Assin and Breman districts of Ghana. A multi-criteria approach was used in the assessment of the basin granitoids including; electrical resistivity survey, pumping test and water quality analysis. A total of twenty-five (25) representative boreholes were drilled, developed and pumped; obtaining data for aquifer hydraulic parameters estimation. Correlation analysis was used to determine relationships that exist between aquifer hydraulic parameters. Schoeller, Piper, Stiff plot and Gibbs diagrams were used to determine the hydrogeochemical facies, water types and the mechanism that control groundwater quality. The statistical analysis determined that aquifer hydraulic parameters discharge rate $(\mathrm{Q})$, hydraulic conductivity $(\mathrm{K})$ and Transmissivity $(\mathrm{T})$ showed a strong positive correlation with specific capacity $\left(\mathrm{Q} / \mathrm{S}_{\mathrm{w}}\right)$ with $\mathrm{R}$ value 0.8462 , 0.8738 and 0.8332 respectively. The $\mathrm{K}$ and $\mathrm{T}$ were respectively between 0.02 $0.90 \mathrm{~m} /$ day and $0.36-13.47 \mathrm{~m}^{2} /$ day with mean of $0.24 \mathrm{~m} /$ day and $3.03 \mathrm{~m}^{2} /$ day respectively. The $\mathrm{K}$ values indicate a hydrogeological condition of aquiclude with relatively low permeability and medium water bearing capacity. The aquifer $\mathrm{T}$ magnitude is very low to low, groundwater potential is adequate for local water supply with limited and private consumption. All physicochemical parameters were within the permissible limits of Ghana Standards Authority (GSA) and World Health Organisation (WHO) except for apparent colour, $\mathrm{pH}, \mathrm{Fe}$ and $\mathrm{Mn}$. Distribution of major ions in groundwater samples was calculated and the general trend among cations and anions was found to be $\mathrm{Ca}^{2+}>\mathrm{Na}^{+}>\mathrm{Mg}^{2+}$ and $\mathrm{Cl}^{-}>\mathrm{HCO}_{3}^{-}>\mathrm{SO}_{4}^{2-}$ respectively. The study area shows five main water types namely; $\mathrm{Ca}-\mathrm{HCO}_{3}, \mathrm{Na}-\mathrm{Mg}-\mathrm{HCO}_{3}-\mathrm{SO}_{4}, \mathrm{Ca}-\mathrm{SO}_{4}$, $\mathrm{Na}-\mathrm{Cl}$ and $\mathrm{Mg}-\mathrm{Na}-\mathrm{Cl}$. Weathering of rock-forming minerals as the mechanism controlling the groundwater chemistry. Microbiological parameters
\end{abstract}


were above the permissible limits. Groundwater is suitable for drinking after treatment with chlorination, aeration and slow sand filtration methods.

\section{Keywords}

Hydrogeological Assessment, Aquifer Geochemistry, Groundwater Quality, Basin Granitoids, Ghana

\section{Introduction}

The use of groundwater is widespread in Ghana especially for private use, rural communities and areas where accesses to national water networks are limited or not existing. There are concerns and issues regarding sustainable exploitation of groundwater resources. These concerns are because of growth in population and industrialisation, consequently affecting the use and demand of natural resources. Excessive abstraction of groundwater in certain aquifers over a long period of time may lead to overexploitation of the aquifer. Groundwater quality is as important as quantity for satisfying water needs; this has led many studies around the world to examine the quality of water in areas facing water scarcity [1] [2] [3] [4] [5]. Acheampong and Hess [6] state that, for proper development of groundwater resource, an understanding of the hydrogeologic and hydrochemical properties of the aquifer is vital. Although groundwater has a natural quality desirable for drinking purposes and available in areas with no surface water options, polluted aquifers are difficult and expensive to treat.

Several authors have worked in the basin granitoids of Ghana, with the aim of finding portable groundwater resources [4] [7] [8] [9] [10]. The basin granitoids serve as a groundwater source supplying portable water to the regions surrounding the aquifer such as Assin and Bremen districts in Ghana. There is the need to understand the hydrogeological characteristics of the aquifer to enhance sustainable use and prevent overexploitation. The chemical and microbial properties that affect overall groundwater quality needs to be studied. The ions of groundwater are mainly influenced by the characteristics of the catchment area, including: dissolution-precipitation, geological formation and structure, chemistry of rock-forming minerals of the aquifers, oxidation-reduction, transformation of organic matter, geological processes within the aquifer and anthropogenic activities [11]-[18]. The purpose of this study is to conduct hydrogeological and hydrochemical assessment of groundwater; to determine the hydraulic, physicochemical and microbiological properties of the basin granitoids aquifer in Assin and Breman district of Ghana. This will increase our understanding of chemical processes affecting groundwater quality, define the hydraulic characteristics and local relations among aquifer and physicochemical parameters for future development. 


\subsection{The Study Area}

\subsubsection{Location and Accessibility}

The study area is located within the Assin North and Asikuma-Odoben-Brakwa Districts (Figure 1). Assin North Municipal, with the district capital Assin Foso, is located on the central part of the Central Region. It is bordered on the north by Ejura Sekye Dumase District (Ashanti Region), on the northwest by Upper Denkyira East Municipal, on the west and southwest by Twifo Atti Morkwa and Heman Lower Denkyira Districts and on the south by Assin South District, on the southeast by Asikuma Odoben Brakwa and on the east by the Birim South District.

From Cape Coast, the regional seat of administration, the Assin North Municipal can be accessed through the Kumasi-Yamoransa Road traversing Abura Dunkwa and Nsuaem-Kyekyewere. These communities are scattered around the district capital at variable distances, access roads to the communities are generally motorable as shown in Figure 1.

\subsubsection{Topography and Drainage}

The study area has a rolling to undulating topography. The slopes generally trend south from Birim River, the main natural drainage system in the locality and one of the main tributaries of the Pra River. The study area is within the catchment of the Kyeremoa River, a tributary of Birim River.

\subsubsection{Meteorology}

The study area is within the semi equatorial climatic region of Ghana [20]. This zone has characteristically double maximal rainfalls with total annual of $1200 \mathrm{~mm}$

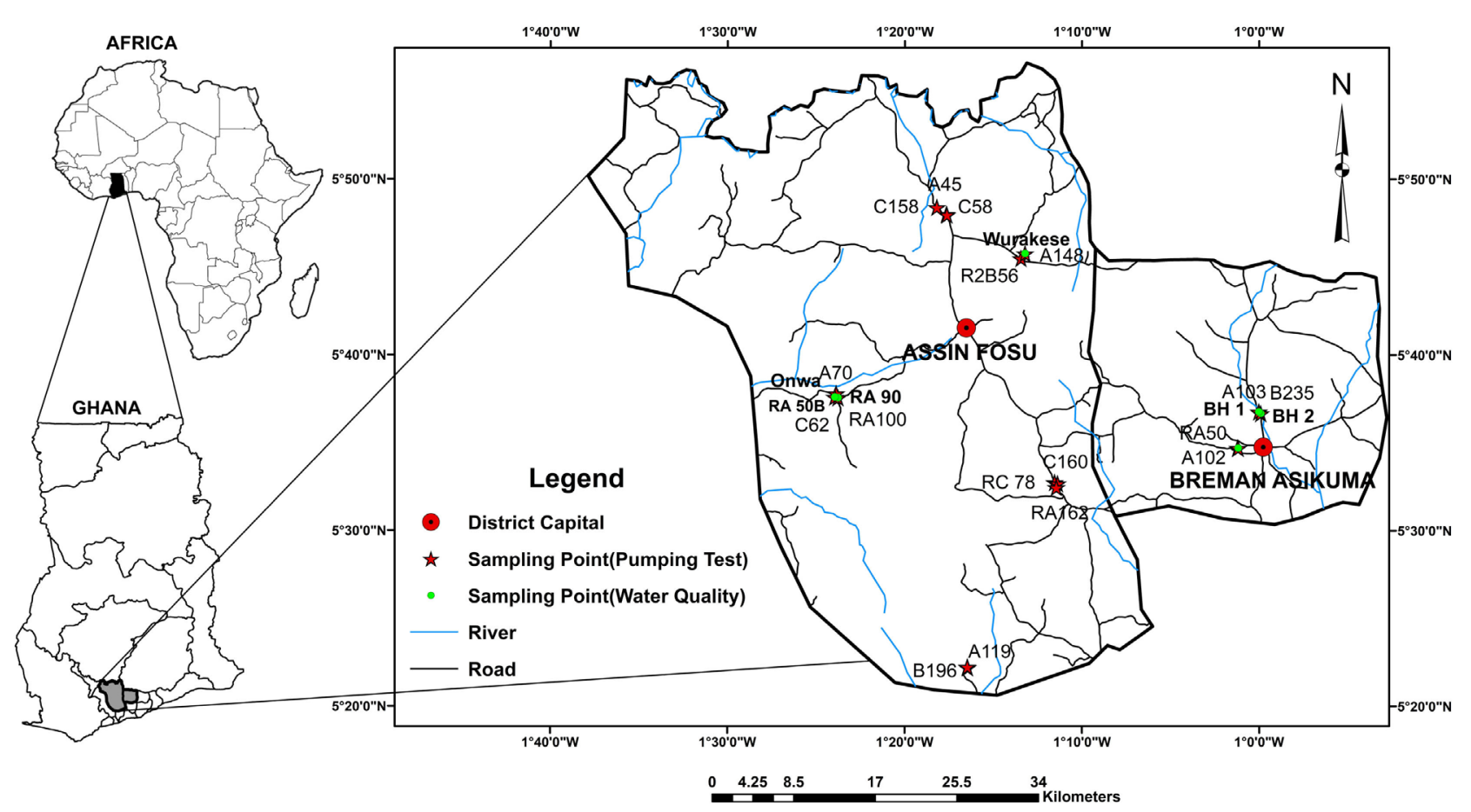

Figure 1. Map of central region showing the study area and sampling locations [19]. 
to $2000 \mathrm{~mm}$. The first rainy season is from May to June and the second season is from September to October. The dry seasons are pronounced, mainly between February and April. The mean annual temperature ranges from $24^{\circ} \mathrm{C}$ to $29^{\circ} \mathrm{C}$. The highest mean monthly temperature of around $30^{\circ} \mathrm{C}$ occurs between March and April and the lowest of about $26^{\circ} \mathrm{C}$ in August. The average monthly relative humidity is reportedly highest $(75 \%-80 \%)$ during the two rainy seasons and lower during the rest of the year.

\subsection{Geology}

Ghana is situated in the West African Craton, a rigid and stable continental part of the earth's crust and upper mantle, formed during the Proterozoic Eon. The southern part of West African Craton is now generally referred to as the Man Shield which is made up of two domains [21]:

1) An Archean nucleus, called Kenema-Man domain, which is composed of geological formations structured during the Leonian and the Liberian orogenies;

2) A Paleoproterozoic domain or Baoulé-Mossi domain, with relics of Archean basement (Which host the Birimian and Tarkwaian rocks).

The Central Region is partly within the Birimian System, the Tarkwaian System, Phanerozoic sedimentary unit (which incorporates Sekondian Formation) and intrusives. Two main types of granitoids namely Cape Coast and Dixcove type granitoids intruded the Birimian during the Paleoproterozoic eon [22]. The Dixcove granitoid is considered by [23] to be older than the Cape Coast granitoid. From the radiometric age dating results, Cape Coast granitoids and Dixcove granitoids, both were contemporaneous and comagmatic; whereas the Cape Coast granitoids were formed at the later part of the deformation [24] [25] [26]. The study area is largely made up the Cape Coast or basin type granitoids as shown in Figure 2. This geological formation covers about $90 \%$ of the basin and is composed of rocks such as gneiss, granites and granodiorites. These gneissic rocks are intruded by both acidic and basic igneous rocks, which include white and pink pegmatite, aplite, granodiorite and dolerite dykes [27] [28].

\subsection{Hydrogeology}

The rocks in the Central Region are crystalline and well consolidated, occurrence of groundwater is minimal due to its negligible primary porosity and permeability. Due to its crystalline nature, the major part of the groundwater flow occurs in secondarily formed structures, mostly fractures, joints and shear zones, and deep weathering in the rocks [27] [28]. The secondary porosity and flow guiding structures have been created mainly by tectonic processes such as folding, mineral orientation, fracturing and faults, shrinking during cooling of rock mass and weathering [28] [29].

These deformations led to the development of two distinct types of aquifers in the basin, which are; the fractured zone aquifer and the weathered zone aquifer. Fractured aquifers are very different from porous aquifers as these groundwater 


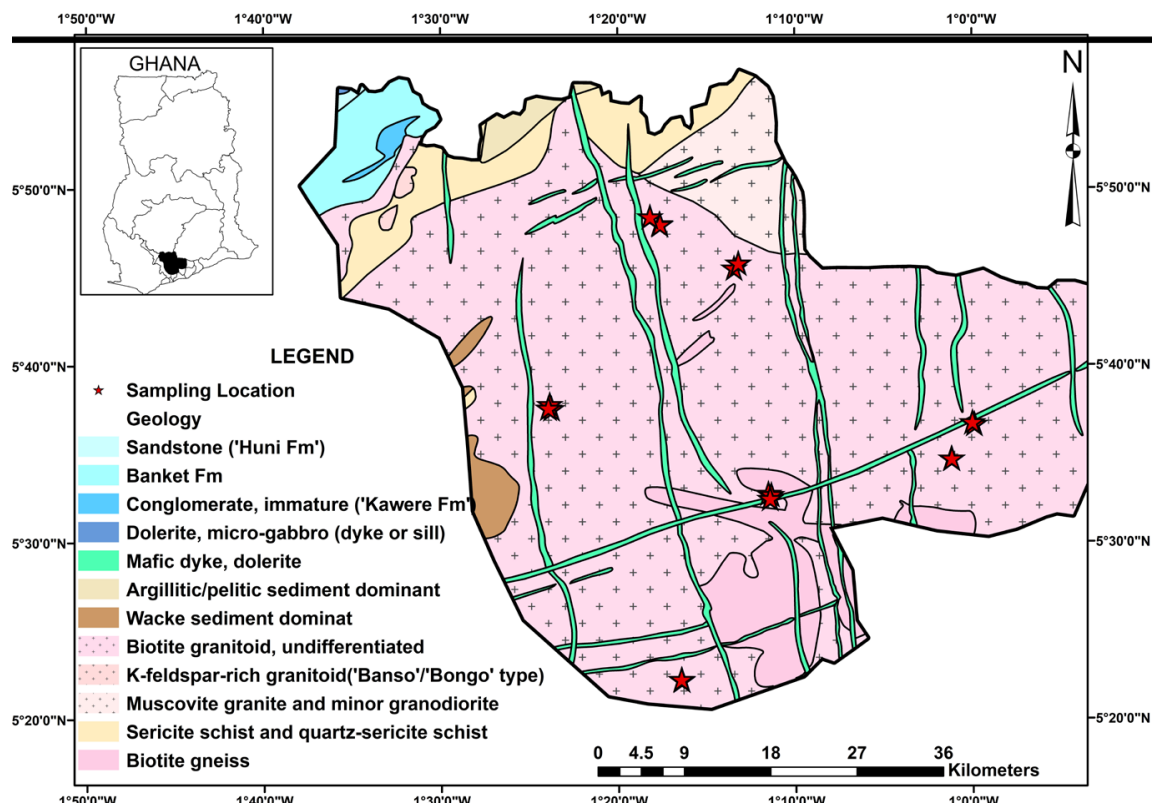

Figure 2. Geological map of Assin and Breman districts.

reservoirs have limited extent (vertically and horizontally). Occurrence of groundwater and borehole yields within the fractured zone are determined by the nature, extent, interconnection and degree of fracturing [30] [31]. Groundwater in fractured aquifers tends to be less predictable and less reliable than in porous aquifers as different types of fractures develop in different rocks or geologic environment with different size, distribution and pattern as wells as fluid-flow characteristics which vary with fracture surface smoothness [32].

Weathering of the basin granitoid is relatively thin and produces sandy soils and this favours meteoric water percolation into the ground [8]. It is common to have dense fractures near the surface than at greater depths. The degree of weathering is dependent of the mineralogical composition of rocks, degree of fracturing and amount of precipitation [32]. Quartzite, granite, gneiss and granodiorite are relatively resistant to weathering and form sandy soils. Leaching of some mineral in the weathered zones increase rock porosity and permeability. Depth of weathering is thicker in the sedimentary basin and volcanic belt compared to the crystalline basement rocks made of the granitoids [4]. Thus, the targets for groundwater development in the project area are weathered zones, thrusted or tectonised lithologic bodies, contacts of intrusives, and highly fractured silica-rich and silicified rocks.

The widespread granitic terrain in the Central Region is regarded as difficult area for groundwater development. Potential areas for mechanised boreholes are the contacts with the meta-sediments and meta-volcanics of the Birimian Supergroup, where cooling fractures that is due to thermal stress and characteristically with polygonal pattern and silicification occurred [4]. The thickness zone of the basin granitoids varies greatly depending on the climatic conditions of the rocks and ranges from 4 to $20 \mathrm{~m}$ as a unit [33]. In most communities, the weathered 
zone aquifer is developed for water supply by hand-dug wells [34], but most of these wells dry up during the dry season. The thick weathered zones occur in the forested area in the basin.

A formation which combines the thick weathered zone with well fractured bedrock provides the most productive aquifers. The granitic aquifers thus formed are usually phreatic to semi-confined in character, structurally dependent and often discontinuous in occurrence [30] [31]. Gibrilla et al. [33] also suggested a relatively high productive wells existed in the northern portion of the granitic formation. Prackley [34], noted that the borehole yields are highly variable and lie in the range of 0.1 to $30.0 \mathrm{~m}^{3} / \mathrm{h}$ with mean value of $2.0 \mathrm{~m}^{3} / \mathrm{h}$ in the granite, while in the Birimian borehole yields range from 0.7 to $9.0 \mathrm{~m}^{3} / \mathrm{h}$ with the mean values of $3.7 \mathrm{~m}^{3} / \mathrm{h}$. However, borehole yields vary from location to location and the chemistry of the groundwater also varies from well to well. The general direction of groundwater is estimated to be from the northern portion of the basin towards the southern portion [35]. During the wet seasons, the water table generally gets higher supplying water to several shallow wells. This also permits the movement of fresh recharge water beyond the weathered zone into the fractured aquifer, particularly in places where there is hydraulic continuity between the weathered zone and the underlying fractures or fissures [30].

\section{Materials and Methods}

\subsection{Hydrogeology}

Possible units in which groundwater occurs were delineated via surface geophysical method such as horizontal electrical resistivity profiling (HERP) and followed by vertical electrical sounding (VES) using the Schlumberger array. The earth resistivity profiling is designed to delineate relatively fractured zone and more porous portion in the weathered horizon in the areas selected through terrain evaluation. HERP was carried out along a set of traverse labelled $\mathrm{A}$ and $\mathrm{B}$. The current and potential separation (L/2, a/2) of 19.0, 0.5 and 40.0, 5.0 was employed for the Schlumberger Array. These electrode configurations ensured that profile data collected at two depth zones, approximately $25 \mathrm{~m}$ and $50 \mathrm{~m}$. The shallow depth profiling is intended for intercepting shallow aquifer and the other for relatively deeper aquifers. The conduct of the profiling was facilitated by a prepared cable set with station interval of $10 \mathrm{~m}$ but narrowed to 1,2 or $3 \mathrm{~m}$ across delineated anomaly zones to precisely locate the centre of the anomalies. Typically, the Schlumberger array was used for the arrangements of the electrodes at each sounding location to determine detailed resistivity variations relative to geologic structures [36], which can provide high resolution of horizontal layer and depths [37]. The VES was used to delineate points determined through earth resistivity profiling. The sounding measurement were recorded on standard data sheet through public domain computer software IPI win, after which resistivity layer models were created. 
Sites delineated by the geophysical survey were drilled, developed and sampled for analysis. Constant pumping rate test was conducted for twenty-five (25) boreholes with each taking nineteen (19) hours for pumping and recovery respectively. Data recorded during the pumping test included; borehole description, GPS location, district and community located, groundwater datum, pump on and off times, pumping and flow rates, static water levels (SWL), dynamic water levels (DWL), drawdowns with time and lithological characteristics. All data were recorded during pumping and recovery phase using Microsoft Excel Spreadsheet; pumping test analysis was done using Aquifer Test Pro software. Data from the aquifer tests were collected from the pumped wells without any water-level measurements from observation wells. Cooper Jacob's [38] method for unsteady state flow for confined aquifer was employed to determine the transmissivity. This method was originally derived for isotropic porous media; however [39] observes that rock aquifers with secondary permeabilities exhibit homogeneous characteristics when sufficiently large volumes of water are considered. Transmissivity as expressed by Cooper Jacob is given by:

$$
T=0.183 Q / \pi \Delta S \text {. }
$$

The slope $(\Delta S)$ is calculated by the software upon the input of well, lithological and pumping parameters. However, adjustment of the line is required for accurate computations. When a line of best fit is obtained the transmissivity is calculated. This was done for both pumping and recovery phase, computing the pumping and the recovery transmissivity respectively. Transmissivity results obtained was used to compute the hydraulic conductivity $(k)$ with the known thickness of the aquifer (screen interval). The specific capacity $\left(S_{c}\right)$ of the well is determined by the ratio of discharge rate $(Q)$ and measured drawdown $\left(S_{w}\right)$ :

$$
S_{c}=Q / S_{w} .
$$

Incorporating specific-capacity data into hydrogeologic assessments allows for a more rigorous characterisation of the hydraulic properties of a regional aquifer and a better understanding of flow in the aquifer [40]. Because specific capacity is relatively easy to measure, several authors have tried to establish empirical relationships between the transmissivity $(T)$ and the specific capacity $\left(Q / S_{w}\right)$ [41] [42] [43] [44]. Empirical analytical relations for fractured granitic $\left(T_{P G}\right)$ and crystalline ( $T_{C}$ ) aquifer, Equation (3) [42] and Equation (4) [41] respectively, were used to compare estimated pumping test transmissivity, this is important for wells where long duration pumping test are not achieved.

$$
\begin{gathered}
T_{F G}=0.12\left(Q / S_{w}\right)^{1.18} \\
T_{c}=0.24\left(Q / S_{w}\right)^{1.07}
\end{gathered}
$$

\subsection{Geochemistry}

Water samples were taken from six (6) representative boreholes to determine its 
quality using a plastic container, sterilised glass bottles and stored in a refrigerator in the laboratory to prevent any changes in the chemical and biological parameters. Each sampling bottle was rinsed thoroughly with filtered water before further filling with sample bottles from the water source. Sampling protocols according to [45] and [46] were adopted.

The chemical analysis of the groundwater samples was carried out using volumetric titration methods for calcium, chloride, sulphate and bicarbonate. While nitrate, iron and manganese were established by a spectrophotometry method, sodium and potassium was also established by flame photometry methods. Graphical representation of the chemical analysis was done using the AqQA software to generate Piper, Schoeller, and Stiff Diagrams. The controlling factor of the groundwater quality was determined using the Gibbs [47] diagram.

\subsection{Contaminant Indicators}

Contaminant indicator are used to describes the degree to which monitoring of ambient concentrations of contaminates such as physicochemical and biological contaminates show exceedances of ambient water quality criteria. Physicochemical indicators are the basic water quality indicators that are widely known. They include $\mathrm{pH}$, temperature, turbidity, dissolved oxygen, salinity and others. They provide information on what is impacting on the system considering toxicant such as insecticides, metals and herbicides. The concentrations of the physicochemical indicators are influenced by the source of water recharging the aquifer, interaction with its surrounding rocks, and movement within the subsurface and sometimes anthropogenic activities.

Biological indicators are direct measures of the health of the fauna and flora in the waterway. The fractures and crevices in these rocks tend to harbour biological growths of microbial organisms such as; bacteria, protozoa, moss and viruses. Organic material in the water can decompose under either aerobic or anaerobic conditions to release toxic substances. Spillage of most septic systems and waste dump sites which are closed to any groundwater body can contribute to the introduction of microbial organism to the groundwater. Commonly used microbiological indicators include various measures of concentration of total coliform, faecal coliform and heterotrophic bacteria. Bacteriological analysis was done using the pour plate count method to determine the presence and abundance of bacteria. $1 \mathrm{ml}$ of each sample was taken into a pour plate with different pipette and $10 \mathrm{ml}$ of MacConkey agar was added. This was then incubated at $37^{\circ} \mathrm{C}$ for total coliform and $44^{\circ} \mathrm{C}$ for faecal coliform and left-over night for fermentation to take place, and the number of spots observed in the plate was counted and recorded. Membrane filtration method was used to measure standard and heterotrophic plate count for $E$. coli and heterotrophic bacteria respectively. Both physicochemical ( $\mathrm{pH}$, colour, TDS, major ions, Nitrates, Fe and $\mathrm{Mn}$ ) and microbial (faecal and total coliforms) parameters were used as contaminant indicators for the study areas. 


\section{Results and Discussions}

\subsection{Aquifer Parameters}

\subsubsection{Descriptive Statistics of Aquifer Parameters}

A summary of the descriptive statistics of the ten (10) parameters considered for the twenty-five (25) boreholes are given in Table 1. The box and whisker plot in Figure 3 give information regarding the shape, variability and the centre or median of all the ten aquifer parameters. The parameters DWL, $Q$ and $S$ have outliers indicated either below or above the whiskers of those parameter plots in Figure 3.

The boreholes were within the elevation (ELV) of $299.9 \mathrm{~m}-374.7 \mathrm{~m}$ with a mean of $333.99 \mathrm{~m}$. The total depth of borehole taping the aquifer ranged between $35 \mathrm{~m}-90 \mathrm{~m}$ with a mean of 63.68. The static water level (SWL) and dynamic water level (DWL) was respectively between $1.09 \mathrm{~m}-14.75 \mathrm{~m}$ and 16.14

Table 1. Summary statistics of aquifer parameters for Assin and Breman districts.

\begin{tabular}{cccccc}
\hline Variable & $\mathrm{N}$ & Mean & Std Dev & Minimum & Maximum \\
\hline ELV $(\mathrm{m})$ & 25 & 333.99 & 24.66 & 299.90 & 374.70 \\
$\mathrm{DEPTH}(\mathrm{m})$ & 25 & 63.68 & 13.91 & 35.00 & 90.00 \\
$\mathrm{SWL}(\mathrm{m})$ & 25 & 4.69 & 3.61 & 1.09 & 14.75 \\
$\mathrm{DWL}(\mathrm{m})$ & 25 & 38.64 & 13.28 & 16.14 & 80.11 \\
Aquifer $(\mathrm{m})$ & 25 & 13.88 & 3.68 & 9.00 & 23.00 \\
$\mathrm{Q}\left(\mathrm{m}^{3} /\right.$ day $)$ & 25 & 193.82 & 140.26 & 86.4 & 576 \\
$\mathrm{~K}(\mathrm{~m} /$ day $)$ & 25 & 0.24 & 0.23 & 0.02 & 0.90 \\
$\mathrm{~T}\left(\mathrm{~m}^{2} /\right.$ day $)$ & 25 & 3.03 & 3.09 & 0.36 & 13.47 \\
$\mathrm{~T}_{\mathrm{FG}}\left(\mathrm{m}^{2} /\right.$ day $)$ & 25 & 1.14 & 0.96 & 0.13 & 3.71 \\
$\mathrm{~T}_{\mathrm{C}}\left(\mathrm{m}^{2} /\right.$ day $)$ & 25 & 1.80 & 1.38 & 0.27 & 5.39 \\
$\mathrm{~S}_{\mathrm{w}}(\mathrm{m})$ & 25 & 33.89 & 12.63 & 13.95 & 78.69 \\
$\mathrm{Q} / \mathrm{S}_{\mathrm{w}}\left(\mathrm{m}^{3} /\right.$ day/m) & 25 & 6.47 & 4.65 & 1.10 & 18.32 \\
\hline
\end{tabular}

$\mathrm{T}_{\mathrm{FG}}-$ Transmissivity Fractured Granite; $\mathrm{T}_{\mathrm{C}}-$ Transmissivity Crystalline.

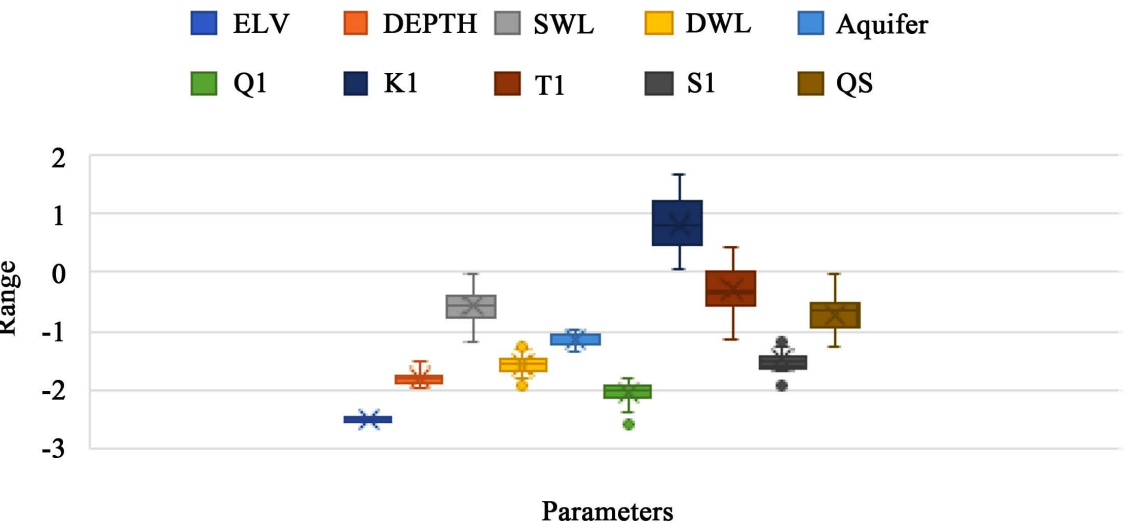

Figure 3. Boxplot of aquifer parameters. 
$\mathrm{m}-80.11 \mathrm{~m}$ with mean of $4.69 \mathrm{~m}$ and $38.64 \mathrm{~m}$ respectively. The aquifer thickness (Aquifer) ranged between $9 \mathrm{~m}-23 \mathrm{~m}$ with mean of $13.88 \mathrm{~m}$ whilst the discharge ranged between $86-576 \mathrm{~m}^{3} /$ day with mean of $193.82 \mathrm{~m}^{3} /$ day. The drawdown $S_{w}$ ranged from $13.95 \mathrm{~m}-78.69 \mathrm{~m}$ with an average of $33.89 \mathrm{~m}$. The specific capacity $\left(Q / S_{w}\right)$ ranged from $1.1-18.32 \mathrm{~m}^{3} /$ day $/ \mathrm{m}$ with mean of $6.47 \mathrm{~m}^{3} /$ day $/ \mathrm{m}$.

The hydraulic conductivity $(K)$ and transmissivity $(T)$ was respectively between $0.02-0.90 \mathrm{~m} /$ day and $0.36-13.47 \mathrm{~m}^{2} /$ day with mean of $0.24 \mathrm{~m} /$ day and $3.03 \mathrm{~m}^{2} /$ day respectively. Empirical analytical relations for fractured granitic $\left(T_{F G}\right)$ and crystalline $\left(T_{C}\right)$ aquifer respectively ranged between $0.13-13.47$ $\mathrm{m}^{2} /$ day and $0.27-5.39 \mathrm{~m}^{2} /$ day with mean of 1.14 and $1.80 \mathrm{~m}^{2} /$ day respectively. Figure 4 shows a comparison between the pumping test transmissivity (T) and the estimated analytical transmissivity $\left(T_{F G}\right.$ and $\left.T_{C}\right)$. Seven (7) boreholes representing $28 \%$ of the total boreholes had pumping test transmissivity to be higher than the analytical transmissivity.

The rest of the eighteen (18) boreholes (72\% of total boreholes) had pumping test transmissivity of the same order magnitude as the estimated analytical transmissivity as shown in Figure 4.

According to [48], the $K$ values indicates a hydrogeological condition of aquiclude with relatively low permeability and medium water bearing capacity. The $\mathrm{T}$ values falls within the class of V (very low) and IV (low) transmissivity magnitude for Krásný's classification [49]. The corresponding groundwater potential is withdrawals for local water supply with limited and private consumption.

\subsubsection{Correlation Analysis of Aquifer Parameters}

Pearson correlation matrix was generated for the ten (10) aquifer parameters in Table 2 to determine the relationship between the parameters. The correlation is presented in a block matrix form, each matrix entry is made up of a correlated value and its significant value in parenthesis. The correlation between the parameters were tested at 5\% significant level (95\% Confidence Level).

The correlated values were measured on a scale of -1 to +1 , with values very close to $+1(>+0.7)$ being strong positively correlated and those close to -1

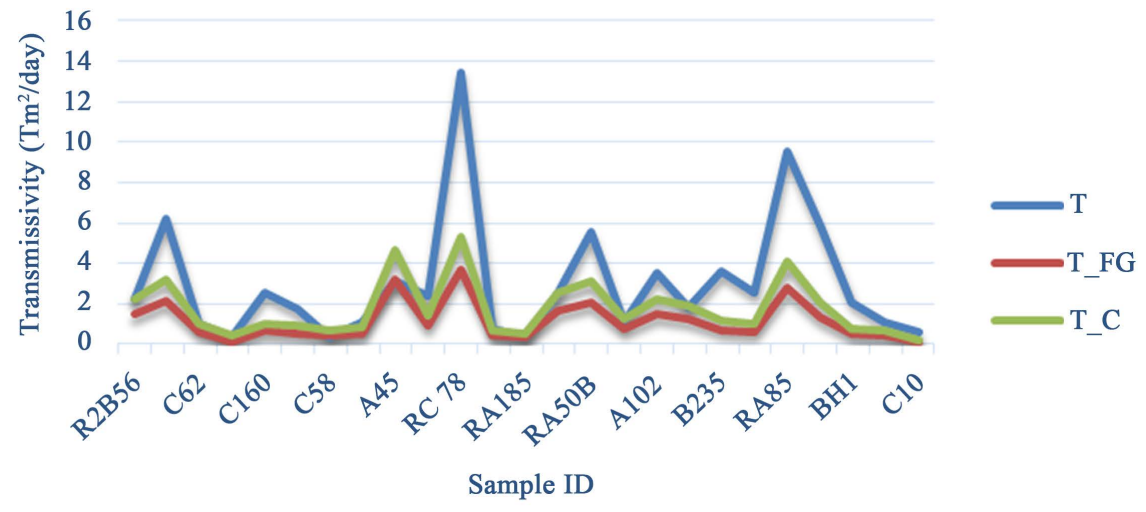

Figure 4. Comparison of pumping test Transmissivity (T) and Estimated Analytical Transmissivity $\left(\mathrm{T}_{\mathrm{FG}}\right.$ and $\left.\mathrm{T}_{\mathrm{C}}\right)$. 
Table 2. Pearson correlation matrix of aquifer parameters.

\begin{tabular}{|c|c|c|c|c|c|c|c|c|c|c|}
\hline Parameters & ELV & DEPTH & SWL & DWL & Aquifer & Q & K & $\mathrm{T}$ & $\mathrm{S}_{\mathrm{w}}$ & $\mathrm{Q} / \mathrm{S}_{\mathrm{w}}$ \\
\hline ELV & 1.000 & & & & & & & & & \\
\hline DEPTH & $\begin{array}{c}0.1850 \\
(0.3758)\end{array}$ & 1.000 & & & & & & & & \\
\hline SWL & $\begin{array}{c}\mathbf{0 . 5 0 2 4} \\
(0.0105)\end{array}$ & $\begin{array}{c}0.2641 \\
(0.2021)\end{array}$ & 1.000 & & & & & & & \\
\hline DWL & $\begin{array}{c}0.1794 \\
(0.3907)\end{array}$ & $\begin{array}{c}\mathbf{0 . 6 3 4 0} \\
(0.0007)\end{array}$ & $\begin{array}{l}0.3159 \\
(0.124)\end{array}$ & 1.000 & & & & & & \\
\hline Aquifer & $\begin{array}{c}0.3106 \\
(0.1308)\end{array}$ & $\begin{array}{c}0.3014 \\
(0.1432)\end{array}$ & $\begin{array}{c}\mathbf{0 . 5 3 2 4} \\
(0.0062)\end{array}$ & $\begin{array}{c}0.1412 \\
(0.5008)\end{array}$ & 1.000 & & & & & \\
\hline Q & $\begin{array}{c}0.0692 \\
(0.7425)\end{array}$ & $\begin{array}{l}-0.1373 \\
(0.5129)\end{array}$ & $\begin{array}{l}-0.3556 \\
(0.0811)\end{array}$ & $\begin{array}{l}-0.1697 \\
(0.4174)\end{array}$ & $\begin{array}{l}-0.2322 \\
(0.2641)\end{array}$ & 1.000 & & & & \\
\hline K & $\begin{array}{l}-0.1324 \\
(0.5281)\end{array}$ & $\begin{array}{l}-0.2227 \\
(0.2846)\end{array}$ & $\begin{array}{l}-0.3420 \\
(0.0942)\end{array}$ & $\begin{array}{l}-0.4857 \\
(0.0138)\end{array}$ & $\begin{array}{l}-0.2723 \\
(0.1879)\end{array}$ & $\begin{array}{c}\mathbf{0 . 6 7 3 5} \\
(0.0002)\end{array}$ & 1.000 & & & \\
\hline $\mathrm{T}$ & $\begin{array}{l}-0.1006 \\
(0.6324)\end{array}$ & $\begin{array}{l}-0.1631 \\
(0.4359)\end{array}$ & $\begin{array}{l}-0.2685 \\
(0.1944)\end{array}$ & $\begin{array}{l}-0.4595 \\
(0.0208)\end{array}$ & $\begin{array}{l}-0.1225 \\
(0.5598)\end{array}$ & $\begin{array}{c}\mathbf{0 . 6 0 8 2} \\
(0.0013)\end{array}$ & $\begin{array}{c}0.9770 \\
(<.0001)\end{array}$ & 1.000 & & \\
\hline$S_{w}$ & $\begin{array}{c}0.0459 \\
(0.8276)\end{array}$ & $\begin{array}{c}0.5956 \\
(0.0017)\end{array}$ & $\begin{array}{c}0.0439 \\
(0.8348)\end{array}$ & $\begin{array}{c}\mathbf{0 . 9 6 1 7} \\
(<.0001)\end{array}$ & $\begin{array}{l}-0.0059 \\
(0.9776)\end{array}$ & $\begin{array}{l}-0.0739 \\
(0.7255)\end{array}$ & $\begin{array}{l}-0.4117 \\
(0.0409)\end{array}$ & $\begin{array}{l}-0.4051 \\
(0.0445)\end{array}$ & 1.000 & \\
\hline $\mathrm{Q} / \mathrm{S}_{\mathrm{w}}$ & $\begin{array}{l}-0.0326 \\
(0.8769)\end{array}$ & $\begin{array}{l}-0.3407 \\
(0.0956)\end{array}$ & $\begin{array}{l}-0.3577 \\
(0.0792)\end{array}$ & $\begin{array}{r}-0.5277 \\
(0.0067)\end{array}$ & $\begin{array}{l}-0.2632 \\
(0.2037)\end{array}$ & $\begin{array}{c}0.8462 \\
(<0.0001)\end{array}$ & $\begin{array}{c}\mathbf{0 . 8 7 3 8} \\
(<0.0001)\end{array}$ & $\begin{array}{c}0.8332 \\
(<0.0001)\end{array}$ & $\begin{array}{c}-0.4499 \\
(0.024)\end{array}$ & 1.000 \\
\hline
\end{tabular}

The bold value respectively represents correlation and accepted significance at level 0.05 .

(>-0.7) being strong negatively correlated. Values between 0.5 to 0.7 were considered moderate whilst values below 0.5 were considered weak. The linear correlation coefficient of examined aquifer parameters are presented in Table 3.

Aquifer parameters ELV (elevation) and Aquifer (aquifer thickness) showed a moderate positive correlation with SWL (static water level) with R value 0.5024 and 0.5324 respectively. The linear correlation coefficient of SWL with the aquifer parameters in Table 3, showed that the variable between ELV has a low positive correlation of $R^{2}=0.2524$ and with Aquifer also having a low positive correlation of $R^{2}=0.2834$ in Figure 5(c). DWL and $S_{w}$ showed a moderate negative correlation with $Q / S_{w}$ with $R$ value 0.5277 and 0.4499 respectively whilst Q, K and $\mathrm{T}$ showed a strong positive correlation with $Q / S_{w}$ with $R$ value 0.8462 , 0.8738 and 0.8332 respectively. The linear correlation coefficient of $Q / S_{W}$ with examined aquifer parameters in Table 3 , showed that $Q / S_{w}$-DWL and $Q / S_{W}-S_{W}$ has low negative correlation with $\mathrm{R}^{2}$ value of 0.2785 and 0.2024 respectively. The linear correlation coefficient of $Q / S_{w}-Q, Q / S_{W}-K$ and $Q / S_{w^{-}} T$ in Figure 5(a) showed high positive correlation of $\mathrm{R}^{2}$ value $0.7161,0.7636$ and 0.6942 respectively. Aquifer parameters $T$, Depth and DWL showed moderate to strong correlation with $S_{w}$ with $R$ value $-0.4051,0.5956$ and 0.9617 . The linear correlation coefficient of DWL- $S_{w}$ shows a strong correlation with $R^{2}=0.9248$ in Figure 5(b), whereas $T$ and Depth show a weak negative and moderate positive correlation with $R^{2}$ value of 0.1641 and 0.3548 respectively. DWL correlates well 
Table 3. Linear correlation coefficients of examined aquifer parameters.

\begin{tabular}{|c|c|c|c|c|c|}
\hline Variables & Relationship & $\mathrm{R}$ & Remarks & $\mathrm{R} 2$ & Linear Correlation Model \\
\hline SWL-ELV & Positive & 0.5024 & moderate & 0.2524 & $y=0.07359 x-19.8860$ \\
\hline DWL-DEPTH & Positive & 0.6340 & moderate & 0.4019 & $y=0.6051 x+0.1083$ \\
\hline AQUIFER-SWL & Positive & 0.3420 & weak & 0.2834 & $y=0.5421 x+11.336$ \\
\hline K-DWL & Negative & 0.4857 & weak & 0.2359 & $y=-0.00858 x+0.5666$ \\
\hline T-DWL & Negative & 0.4595 & weak & 0.2112 & $y=-0.1070 x+7.1710$ \\
\hline$S_{w}-D W L$ & Positive & 0.9617 & strong & 0.9248 & $y=0.9149 x-1.4628$ \\
\hline $\mathrm{Q} / \mathrm{S}_{\mathrm{w}}-\mathrm{DWL}$ & Negative & 0.5277 & moderate & 0.2785 & $y=-0.1848 x+13.6093$ \\
\hline $\mathrm{Q} / \mathrm{S}_{\mathrm{w}}-\mathrm{Q}$ & Positive & 0.8462 & strong & 0.7161 & $y=0.0404 x+1.0299$ \\
\hline $\mathrm{Q} / \mathrm{S}_{\mathrm{w}}-\mathrm{K}$ & Positive & 0.8738 & strong & 0.7636 & $y=17.3321 x+2.3911$ \\
\hline $\mathrm{Q} / \mathrm{S}_{\mathrm{w}}-\mathrm{T}$ & Positive & 0.8332 & strong & 0.6942 & $y=1.2528 x+2.6657$ \\
\hline $\mathrm{Q} / \mathrm{S}_{\mathrm{w}}-\mathrm{S}_{\mathrm{w}}$ & Negative & 0.4499 & moderate & 0.2024 & $y=-0.1656 x+12.0803$ \\
\hline K-Q & Positive & 0.6735 & moderate & 0.4536 & $y=0.0016 x+0.01700$ \\
\hline T-Q & Positive & 0.6082 & moderate & 0.3699 & $y=0.0193 x+0.4356$ \\
\hline $\mathrm{T}-\mathrm{K}$ & Positive & 0.9770 & strong & 0.9545 & $y=12.8878 x+0.0036$ \\
\hline $\mathrm{S}_{\mathrm{w}}$-DEPTH & Positive & 0.5956 & moderate & 0.3548 & $y=0.5409 x-0.5520$ \\
\hline $\mathrm{S}_{\mathrm{w}}-\mathrm{T}$ & Negative & 0.4051 & weak & 0.1641 & $y=-1.6546 x+38.9127$ \\
\hline
\end{tabular}

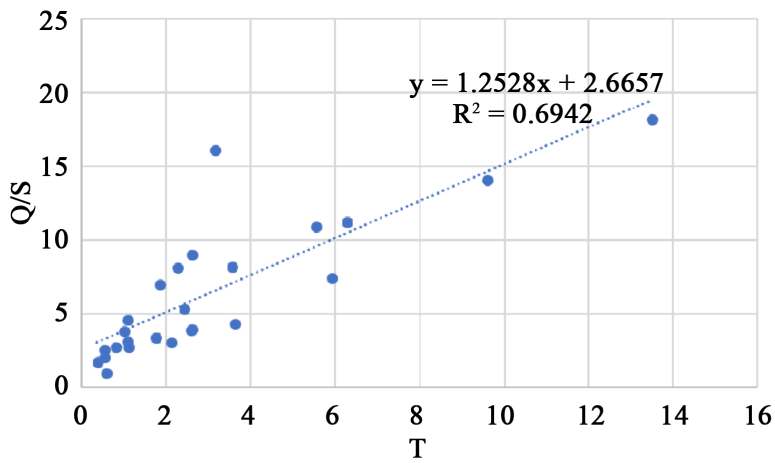

(a)

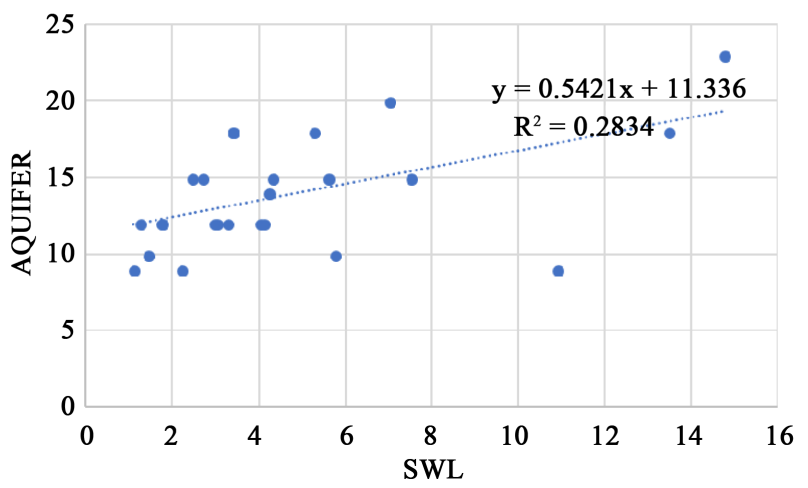

(c)

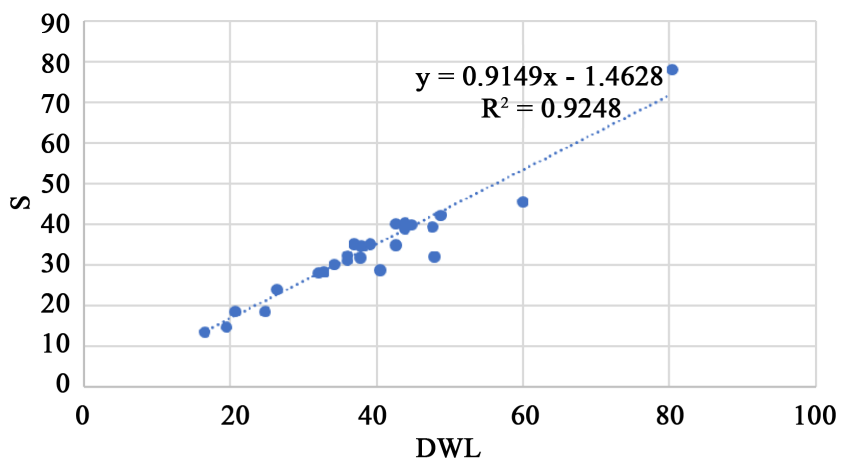

(b)

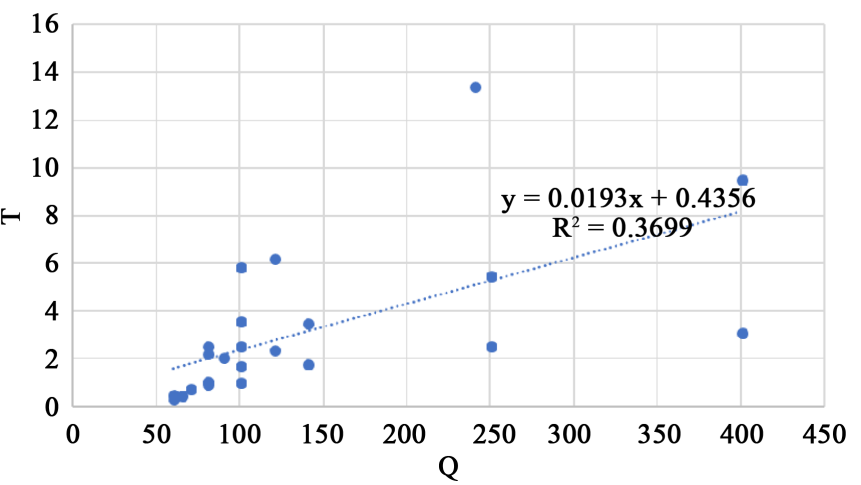

(d)

Figure 5. Linear correlation coefficient of aquifer parameters ((a) Q/S-T; (b) S-DWL; (c) Aquifer-SWL; and (d) T-Q). 
with Depth, $K$ and $T$ with $R$ value of $0.6340,-0.4857$ and -0.4595 respectively. Aquifer parameters $K$ and $T$ correlates well with $Q$ with $R$ value of 0.6735 and 0.6082 . The linear correlation coefficient of $T-Q$ shows a moderate correlation of $R^{2}=0.3699$ in Figure 5(d).

\subsection{Geochemical Parameters}

\subsubsection{Statistics of Physicochemical Parameters}

The results for the physicochemical parameters are reported in Table 4. Apparent colour ranges from 2.50 to $100 \mathrm{~Hz}$ with an average of $24.58 \mathrm{~Hz}$. The $\mathrm{pH}$ value for the various sample ranges from 4.75 to 6.63 with an average of 6.04 , indicating a moderately acidic type of water. Turbidity value ranges from 1 to 28 NTU with an average value of $7.83 \mathrm{NTU}$. Conductivity value ranges from 163 to 514 $\mu \mathrm{S} / \mathrm{cm}$ with an average value of $295 \mu \mathrm{S} / \mathrm{cm}$ while TDS value ranges from 89 to $283 \mathrm{mg} / \mathrm{L}$ with an average value of $162.28 \mathrm{mg} / \mathrm{L}$. Sodium concentration ranges from 8 to $25 \mathrm{mg} / \mathrm{L}$ with an average value of $16.92 \mathrm{mg} / \mathrm{L}$ while Potassium concentration varies from 2.20 to $3.90 \mathrm{mg} / \mathrm{L}$, with an average value of $3.20 \mathrm{mg} / \mathrm{L}$. Calcium concentration varies from 7.30 to $36.70 \mathrm{mg} / \mathrm{L}$ with an average value of $18.63 \mathrm{mg} / \mathrm{L}$ while Magnesium concentration varies from 3 to $16.4 \mathrm{mg} / \mathrm{L}$ with an average value of $8.02 \mathrm{mg} / \mathrm{L}$. Chloride ion concentration varies from 9.90 to 59.60 $\mathrm{mg} / \mathrm{L}$, with an average value of $31.45 \mathrm{mg} / \mathrm{L}$ while Sulphate ion concentration

Table 4. Results of physicochemical analysis for Assin and Breman districts.

\begin{tabular}{cccccccc}
\hline $\begin{array}{c}\text { Code/Town } \\
\text { Parameter }\end{array}$ & RA 50 & RA 90 & Wurakese & BH 2 & BH 1 & Onwa & $\begin{array}{c}\text { GS } 175-1 / \text { WHO } \\
\text { Guideline }\end{array}$ \\
\hline Colour & 37.50 & 100.00 & 2.50 & 2.50 & 2.50 & 2.50 & 15 \\
$\mathrm{pH}$ & 6.63 & 6.59 & 6.13 & 4.75 & 6.40 & 5.75 & $6.5-8.5$ \\
Turbidity & 15.00 & 28.00 & 1.00 & 1.00 & 1.00 & 1.00 & 5 \\
Conductivity & 284.00 & 269.00 & 282.00 & 258.00 & 514.00 & 163.00 & - \\
$\mathrm{TDS}$ & 156.00 & 148.00 & 155.00 & 142.00 & 283.00 & 89.70 & 1000 \\
$\mathrm{TSS}$ & 6.00 & 16.00 & 1.00 & $<1.00$ & $<1.00$ & 1.00 & - \\
$\mathrm{Na}^{+}$ & 10.00 & 8.00 & 25.00 & 15.20 & 10.50 & 33.00 & 200 \\
$\mathrm{~K}^{+}$ & 3.70 & 3.20 & 2.20 & 3.60 & 3.90 & 2.60 & 30 \\
$\mathrm{Ca}^{2+}$ & 24.70 & 17.70 & 13.80 & 7.30 & 36.70 & 11.60 & 200 \\
$\mathrm{Mg}^{2+}$ & 5.90 & 3.40 & 8.80 & 10.60 & 16.40 & 3.00 & 150 \\
$\mathrm{Cl}^{-}$ & 15.90 & 9.90 & 13.90 & 59.60 & 29.80 & 59.60 & 250 \\
$\mathrm{SO}_{4}^{2-}$ & 20.60 & 48.00 & 20.80 & 15.60 & 6.11 & 7.33 & 250 \\
$\mathrm{HCO}_{3}^{-}$ & 79.10 & 61.50 & 97.40 & 23.70 & 150.00 & 40.00 & - \\
$\mathrm{Fe}^{2}$ & 3.41 & 3.73 & 2.79 & 0.07 & 0.09 & 0.14 & 0.3 \\
$\mathrm{Mn}^{-}$ & 0.96 & 1.14 & 0.17 & - & 0.35 & 0.08 & 0.4 \\
$\mathrm{NO}_{3}^{-} \mathrm{N}$ & $<0.001$ & $<0.001$ & 3.35 & 3.10 & $<0.001$ & 1.12 & 10 \\
\hline
\end{tabular}

All parameters in $\mathrm{mg} / \mathrm{L}$ except colour $(\mathrm{Hz})$, conductivity $(\mu \mathrm{S} / \mathrm{cm})$, Turbidity $(\mathrm{NTU})$ and $\mathrm{pH}$. 
varies from 6.11 to $48 \mathrm{mg} / \mathrm{L}$ with an average value of $19.74 \mathrm{mg} / \mathrm{L}$. Bicarbonate concentration varies from 23.70 to $150 \mathrm{mg} / \mathrm{L}$, with an average value of 75.28 $\mathrm{mg} / \mathrm{L}$. Total iron ranges from 0.07 to $3.73 \mathrm{mg} / \mathrm{L}$ with an average of $1.71 \mathrm{mg} / \mathrm{L}$. Manganese concentration varies from 0.08 to $1.14 \mathrm{mg} / \mathrm{L}$ with an average of 0.54 $\mathrm{mg} / \mathrm{L}$ while Nitrate varies from below 0.001 to $3.35 \mathrm{mg} / \mathrm{L}$. Fluoride was below the detectable limit of $0.005 \mathrm{mg} / \mathrm{L}$ whilst Ammonia, Nitrite and Phosphate were below the detectable limit of $0.001 \mathrm{mg} / \mathrm{L}$. All results were compared with the Ghana Standards Authority (GSA) water quality specification for drinking water (GS 175-1) and World Health Organisation (WHO) guidelines for drinking water quality [50] [51]. Colour, $\mathrm{pH}, \mathrm{Fe}$ and $\mathrm{Mn}$ had some results which were not within the guideline values as shown in Table 4 .

\subsubsection{Schoeller Diagram}

Schoeller diagram [52], gives a visual comparison of the various concentration of element present in the various groundwater samples, the major ion trends are shown in Figure 6. The groundwater in the area shows dominance order in concentration of cations and anions as $\mathrm{Ca}^{2+}>\mathrm{Na}^{+}>\mathrm{Mg}^{2+}$ and $\mathrm{Cl}^{-}>\mathrm{HCO}_{3}^{-}>$ $\mathrm{SO}_{4}^{2-}$ respectively.

\subsubsection{Stiff Diagram}

The stiff diagram in Figure 7 shows the various concentration of the major ions, with changes in shape reflecting dominating ions or otherwise. From the diagram, $\mathrm{BH} 1$ had a high and low concentrations of $\mathrm{Ca}, \mathrm{HCO}_{3}$ and $\mathrm{Na}+\mathrm{K}, \mathrm{SO}_{4}$ respectively. $\mathrm{BH} 2$ had high and low concentrations of $\mathrm{Mg}, \mathrm{Cl}$ and $\mathrm{Ca}, \mathrm{HCO}_{3}$ respectively. Onwa had high and low concentrations of $\mathrm{Na}+\mathrm{K}, \mathrm{Cl}$ and $\mathrm{Mg}, \mathrm{HCO}_{3}$. RA 50 had a high and low concentration of $\mathrm{Ca}, \mathrm{HCO}_{3}$ and $\mathrm{Mg}, \mathrm{Cl}$ respectively while RA 90 had a high and low concentrations of $\mathrm{Ca}, \mathrm{SO}_{4}$ and $\mathrm{Mg}, \mathrm{Cl}$ respectively.

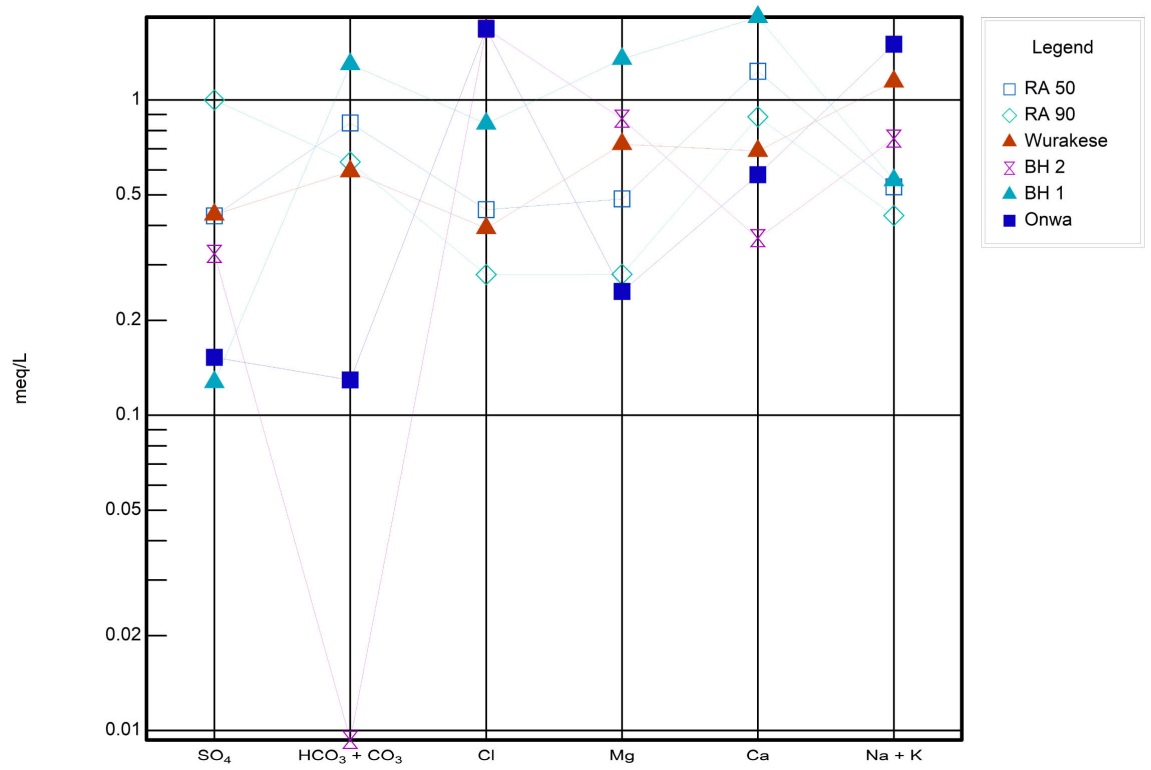

Figure 6. Schoeller graph of major ions. 


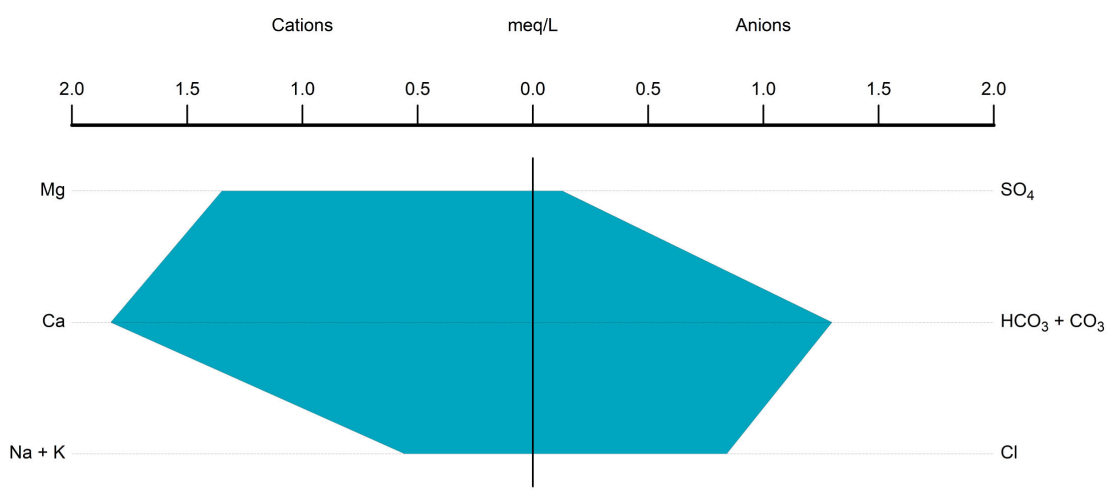

(a)

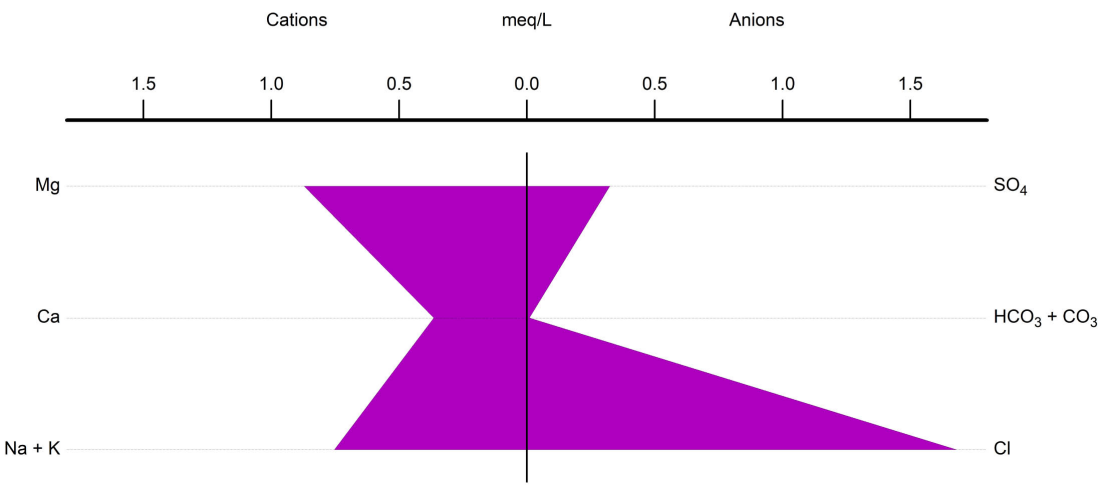

(b)

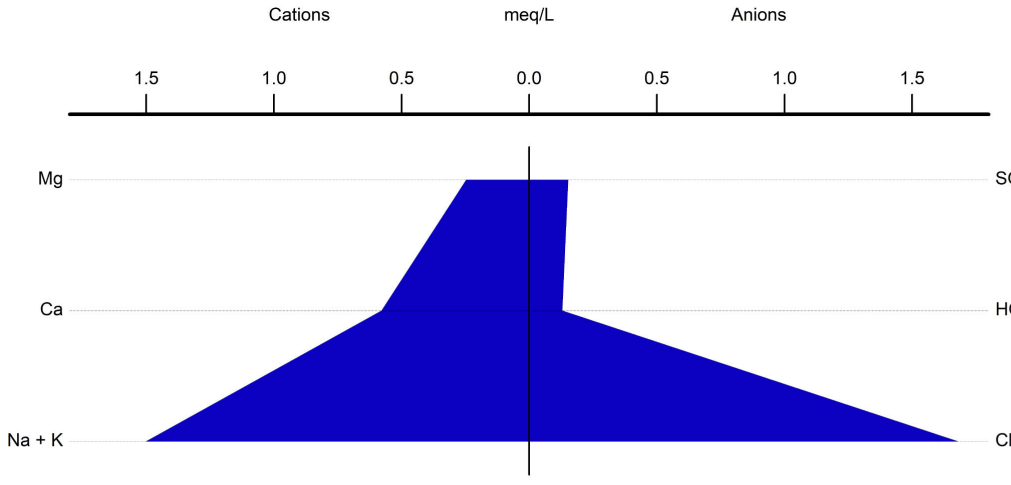

$\mathrm{SO}_{4}$

(c)

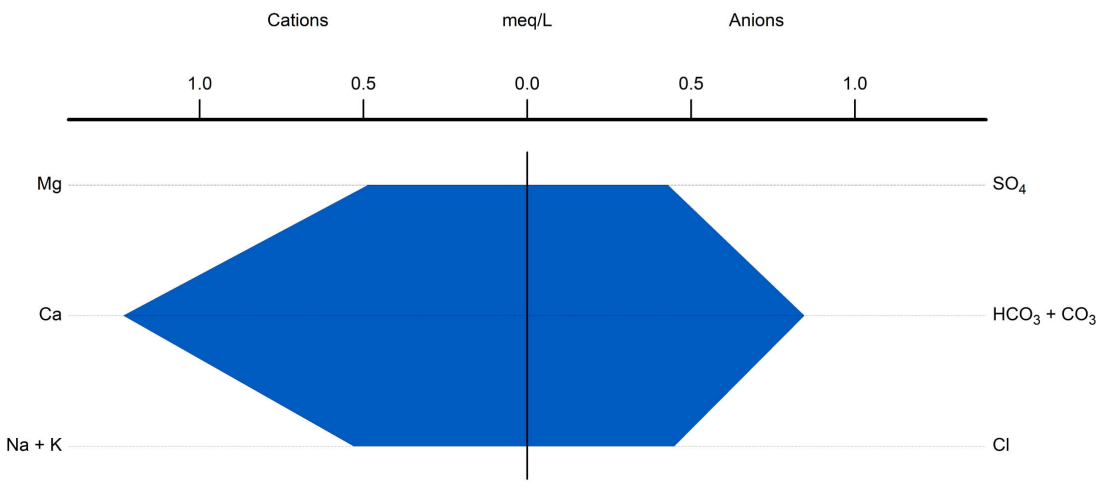

(d) 


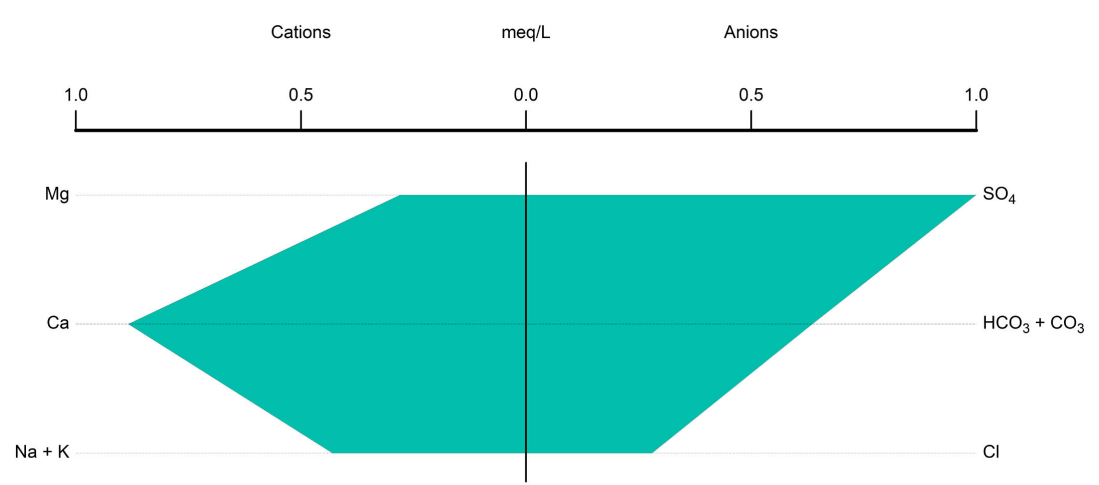

(e)

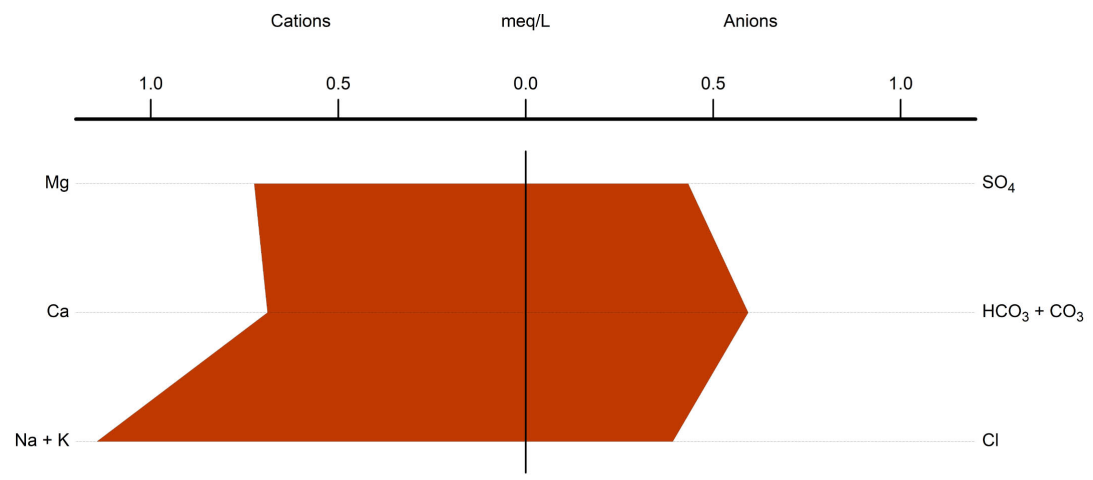

(f)

Figure 7. Stiff diagrams for the study area ((a) BH 1; (b) BH 2; (c) Onwa; (d) RA 50; (e) RA 90; and (f) Wurakese).

Wurakese had a high and low concentrations $\mathrm{Na}, \mathrm{HCO}_{3}$ and $\mathrm{Ca}, \mathrm{Cl}$ respectively. Five main water types are observed from the stiff patterns namely $\mathrm{Ca}-\mathrm{HCO}_{3}$, Na$\mathrm{HCO}_{3}, \mathrm{Ca}-\mathrm{SO}_{4}, \mathrm{Na}-\mathrm{Cl}$ and $\mathrm{Mg}-\mathrm{Cl}$ type.

\subsubsection{Piper Diagram}

To further evaluate and interpret the groundwater composition in the study area, major ions were expressed in units of milliequivalents per litre $(\mathrm{meq} / \mathrm{L})$ and plotted on Piper trilinear diagram in Figure 8. This allows for characterisation of distinct water types by plotting in various subareas of the diamond. Details regarding the geochemical interpretation of water samples can be found in [53] and [54].

The study area has high $\mathrm{HCO}_{3}+\mathrm{Cl}$ relative to $\mathrm{SO}_{4}$ (see anion triangle in Figure 8). In the cation triangle, about $50 \%$ of the sample set (BH1, RA 50 and RA 90) was Ca-type, $33 \%$ of the sample set (BH2 and Wurakese) showed no dominant type of cation and only sample Onwa was of the $\mathrm{Na} / \mathrm{K}$-type. Of the six (6) samples, three (3) represented $50 \%$ of the analysed water samples, fall in area 6 , indicating no dominant cation-anion pair. One sample fall in area 1 indicating that the chemical properties of groundwater are dominated by alkaline earths $(\mathrm{Ca}, \mathrm{Mg})$ and strong acids $\left(\mathrm{SO}_{4}, \mathrm{Cl}\right)$. One sample fall in area 2 indicating the dominance of alkaline earths and weak acids. 


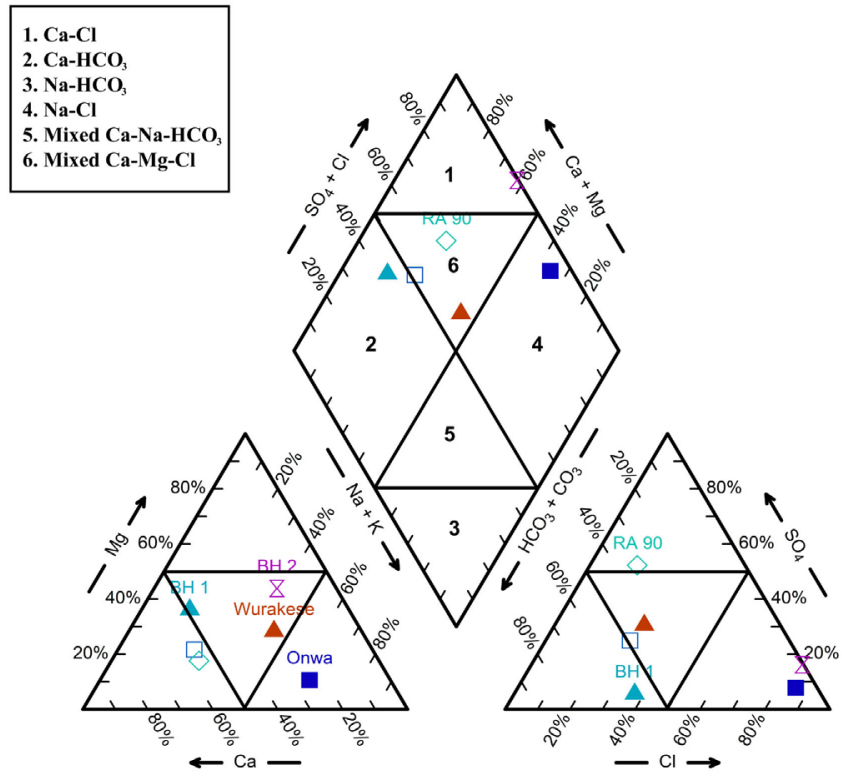

Legend

Wurakese

$\triangle \mathrm{BH} 2$

$\mathrm{BH} 1$
- Onwa

Figure 8. Piper diagram of groundwater facies.

One sample fall in area 4 indicating the dominance of alkalis and strong acids. None of the samples fall in the area designated for alkalis and weak acids (area 3). In summary, most samples are characterised by the dominance of $\mathrm{Ca}, \mathrm{Na}$, $\mathrm{HCO}_{3}$ and $\mathrm{SO}_{4}$. The piper trilinear diagram indicates five water types [55]: $\mathrm{Ca}-\mathrm{HCO}_{3}, \mathrm{Na}-\mathrm{Mg}-\mathrm{HCO}_{3}-\mathrm{SO}_{4}, \mathrm{Ca}-\mathrm{SO}_{4}, \mathrm{Na}-\mathrm{Cl}$ and $\mathrm{Mg}-\mathrm{Na}-\mathrm{Cl}$. Comparison of stiff and piper analysis gives the following water types for the study areas: $\mathrm{Ca}-\mathrm{HCO}_{3}$ type for RA 50 and $\mathrm{BH} 2, \mathrm{Ca}-\mathrm{SO}_{4}$ type for RA 90, $\mathrm{Na}-\mathrm{Mg}-\mathrm{HCO}_{3}-\mathrm{SO}_{4}$ type for Wurakese, $\mathrm{Mg}-\mathrm{Na}-\mathrm{Cl}$ type for $\mathrm{BH} 2$ and $\mathrm{Na}-\mathrm{Cl}$ type for Onwa.

\subsubsection{Gibbs Phase Diagram}

Gibb's diagram [47] is used to determine the source of ions contributing to the groundwater. It has three distinct fields namely; precipitation dominance, rock dominance and evaporation dominance. The Gibbs ratio $\mathrm{Na}+\mathrm{K} /(\mathrm{Na}+\mathrm{K}+\mathrm{Ca})$ for cations and $\mathrm{Cl} /\left(\mathrm{Cl}+\mathrm{HCO}_{3}\right)$ for anions of water samples are plotted separately against the respective TDS in $\mathrm{mg} / \mathrm{L}$. Both type show rock dominance in controlling the quality of ground water in Figure 9. Gibbs diagram suggests that chemical interaction between rock forming minerals of aquifer and the groundwater is the main mechanism in contributing ions to the groundwater. Calcsilicate rocks associated with basin granitoids may have contributed the calcium ions in abundance to the groundwater.

\subsubsection{Spatial Distribution of Hydrochemical Coefficients and Trace Metals}

The spatial distribution of the hydrochemical coefficients $\mathrm{Ca} / \mathrm{Mg}$ and $\mathrm{Na} / \mathrm{Cl}$ in Figure 10(a) and Figure 10(b) shows the change in concentration over the study area. The concentration of $\mathrm{Ca} / \mathrm{Mg}$ in Figure 10 (a) increases from the northeast to southwest direction. The concentration of $\mathrm{Na} / \mathrm{Cl}$ is low at the 


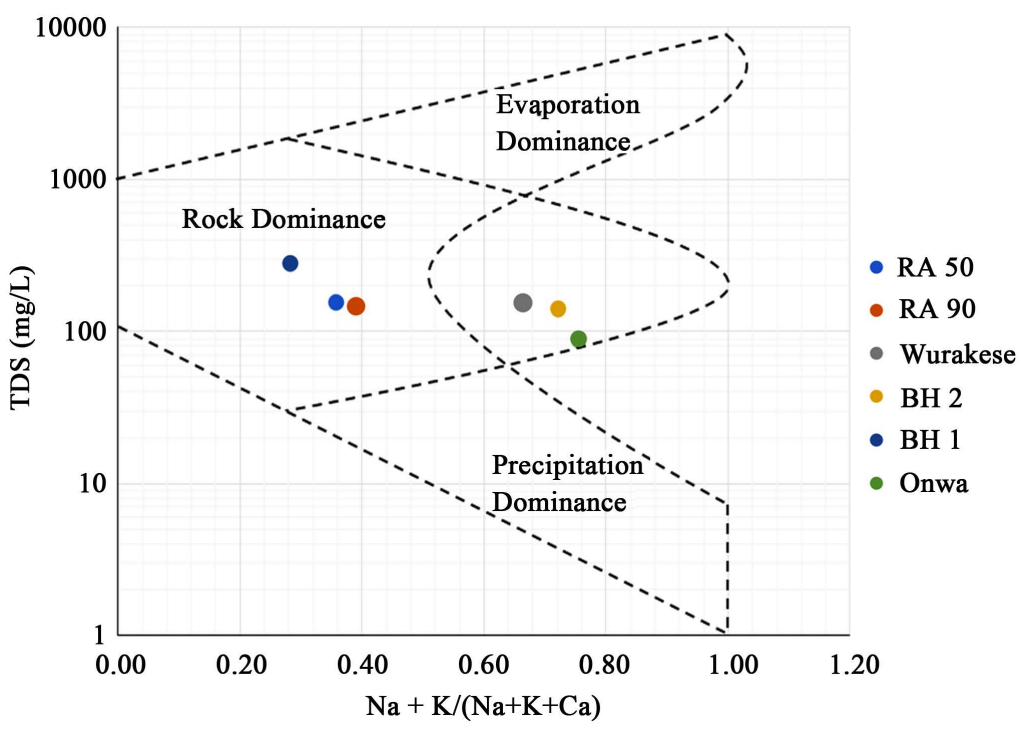

(a)

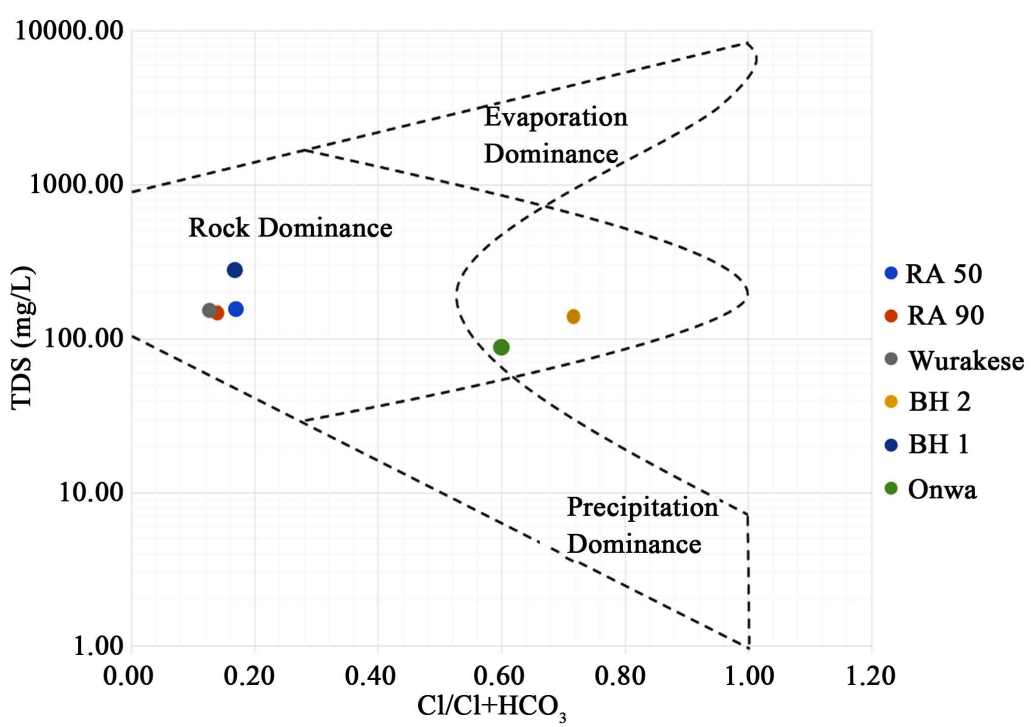

(b)

Figure 9. Mechanism controlling the groundwater chemistry ((a) Cations and (b) Anions).

eastern and increases from southwest to northeast parts in Figure 10(b). The spatial distribution of manganese shows a low concentration at northeast to east and high concentration in the southwest parts of the study area in Figure 10 (c). Spatial distribution of iron shows a high and low concentration in the west and east respectively; $\mathrm{pH}$ is low on the eastern side of the study area and probably show a direct relationship with Fe in Figure 10(d). Hydrogeochemical coefficients of great importance in the field of groundwater chemistry and have been used to determine the flow direction and process of controlling groundwater condition [56] [57]. The general flow direction of $\mathrm{Na} / \mathrm{Cl}$ ratio is towards northeast and northwest, hence it can be deduced that the general flow direction is 


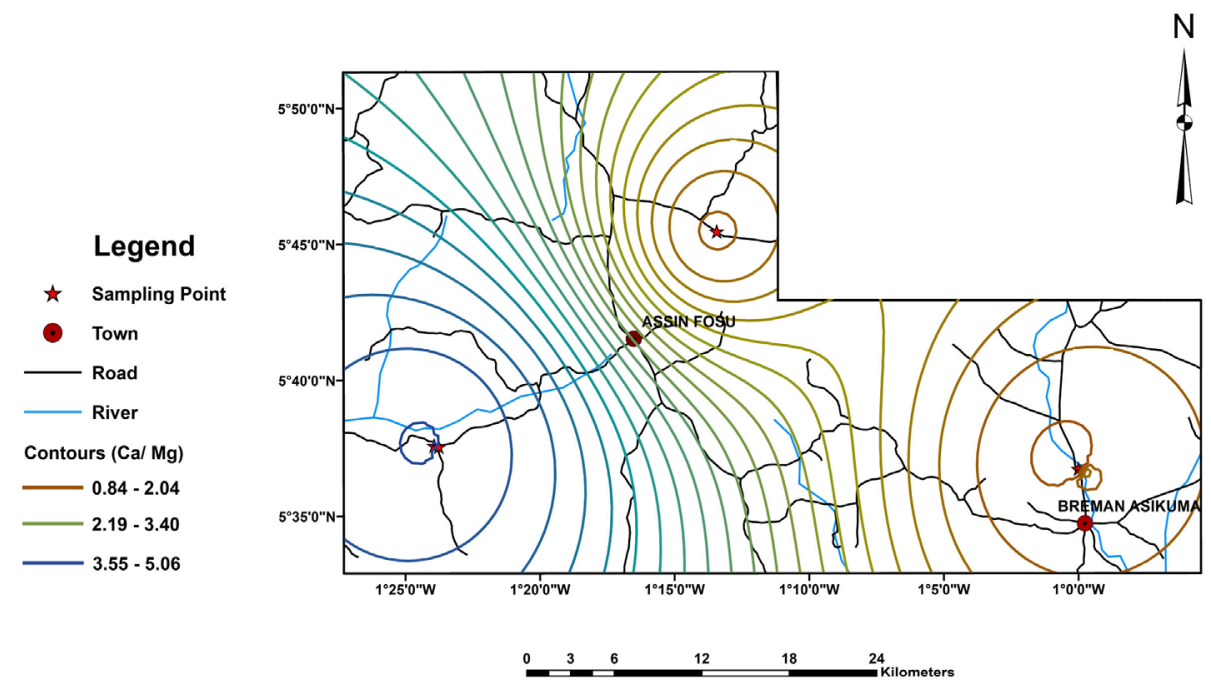

(a)

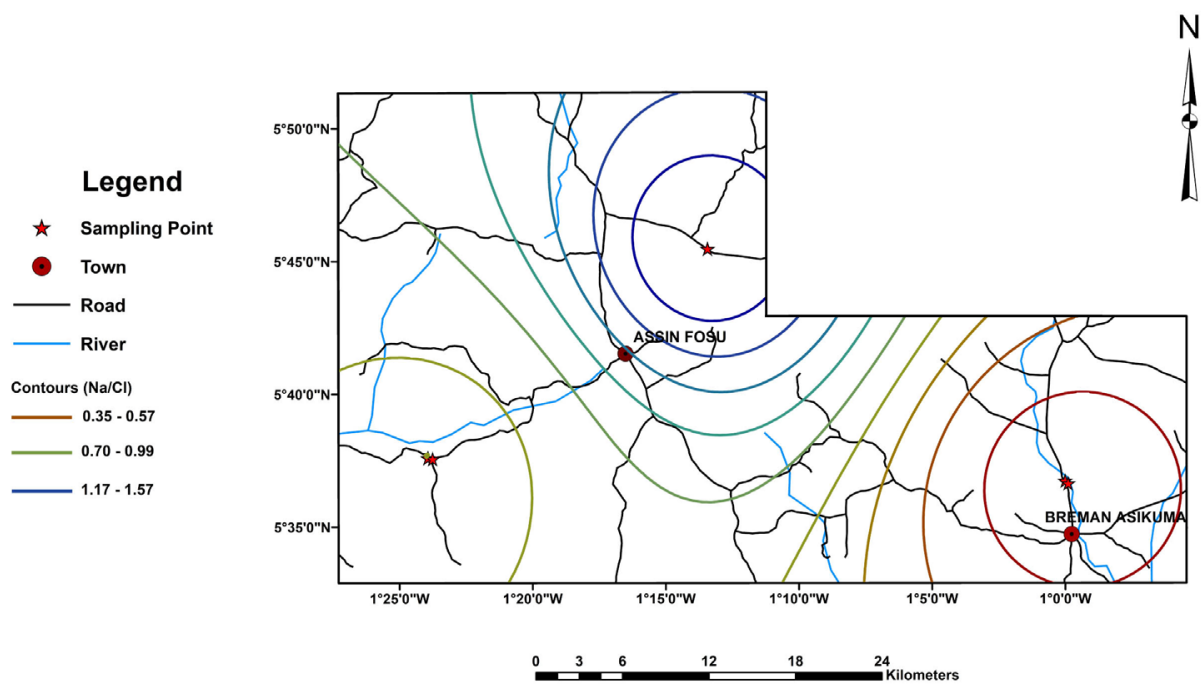

(b)

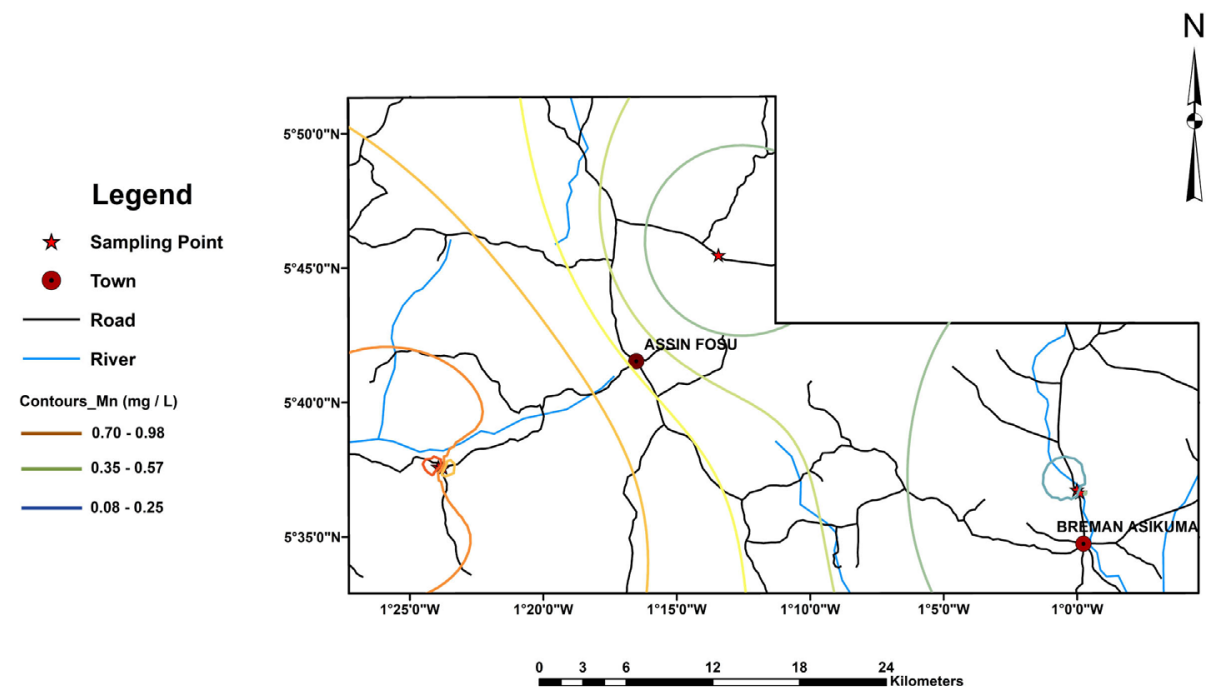

(c) 

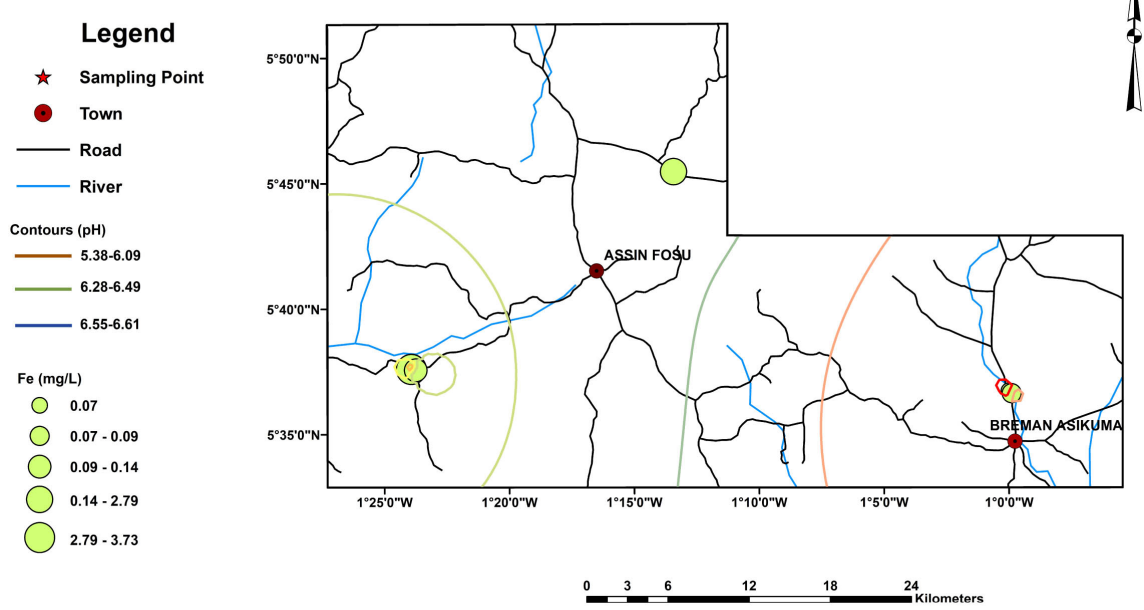

(d)

Figure 10. Spatial distribution of hydrogeochemical coefficients and trace metals ((a) $\mathrm{Ca} / \mathrm{Mg}$, (b) $\mathrm{Na} / \mathrm{Cl}$, (c) $\mathrm{Mn}$ and (d) $\mathrm{pH}-\mathrm{Fe}$ ).

northeast and northwest which also coincides with the general lineation of the study area in Figure 2. The southwestern flank of the study area seems to have high concentrations of trace metals Fe and Mn.

\subsection{Microbiological Parameters}

The results of the microbial quality of the groundwater in the study area are represented by the microbiological parameters; Total Coliform (TC), Faecal Coliform (FC), E. coli (Escherichia coli) and Total Heterotrophic Bacterial (THB) with average concentration of $45.2,11,2 \mathrm{cfu} / 100 \mathrm{ml}$ and $645 \mathrm{cfu} / 1 \mathrm{ml}$ respectively in Table 5. The results indicate that the microbial quality is at levels higher than WHO and GS values of zero counts per $100 \mathrm{~mL}$ for drinking water, however there were no microbes detected in sample RA 50.

\subsection{Contaminant Sources}

Colour, $\mathrm{pH}, \mathrm{Fe}$ and $\mathrm{Mn}$ are the natural physicochemical contaminants in the study area, resulting from the weathering of the crystalline basement granitoids. The high concentrations of $\mathrm{Fe}$ and $\mathrm{Mn}$ are affected by low $\mathrm{pH}$ groundwaters in anaerobic environment or forest zones; which in turn also affect the apparent colour.

Contamination resulting from low $\mathrm{pH}, \mathrm{Fe}$ and $\mathrm{Mn}$ in groundwater in Ghana have been reported by several authors, have been partly attributed to the bedrock of aquifers as they have relatively high iron and manganese content [58]-[65].

The presence of microbiological parameters such as total and faecal coliforms; E. coli and total heterotrophic bacteria in groundwater indicates the presence of microbial contaminants. These pathogens occur naturally in the environment from soils and plants and in the intestines of humans and other warm-blooded 
Table 5. Results of microbiological analysis for Assin and Breman districts.

\begin{tabular}{cccccccccccc}
\hline Parameter & Method & GS/WHO & $\begin{array}{c}\text { RA } \\
50\end{array}$ & $\begin{array}{c}\text { RA } \\
90\end{array}$ & Wurakese & BH 2 & BH 1 & Onwa & Av & Av $^{1}$ \\
\hline TC & $\begin{array}{c}\text { Pour plate } \\
\text { count }\end{array}$ & 0 & - & 12 & 14 & 55 & 79 & 66 & 45.2 & 0 \\
FC & $\begin{array}{c}\text { Pour plate } \\
\text { count }\end{array}$ & 0 & - & 2 & 4 & 13 & 19 & 17 & 11 & 0 \\
E. coli & $\begin{array}{c}\text { MF-Standard } \\
\text { plate count }\end{array}$ & 0 & - & 1 & 0 & 4 & 2 & 3 & 2 & 0 \\
THB & $\begin{array}{c}\text { MF-Heterotrop- } \\
\text { hic plate count }\end{array}$ & 500 & - & 520 & 83 & 836 & 792 & 994 & $645<500$ \\
\hline
\end{tabular}

TC-Total Coliform, FC-Faecal Coliform and E. coli (Parameters in cfu/100ml); Total Heterotrophic Bacteria (THB) cfu/1ml; Av-Average; Av - Av after treatment; GS 175-1/WHO Guideline; MF-Membrane Filtration.

animals. They are associated with domestic waste, faecal sources from animals and humans; getting into groundwater through natural or anthropogenic pathways. These contaminants both natural and man-made when untreated are undesirable or harmful for human consumption. Iron imparts a bitter astringent taste to water and a brownish colour to laundered clothing and plumbing fixtures whilst Manganese causes aesthetic and economic damage and imparts brownish stains to laundry. Affects taste of water and causes dark brown or black stains on plumbing fixtures. Relatively non-toxic to animals but toxic to plants at high levels [51]. High $\mathrm{pH}$ causes a bitter taste; water pipes and water-using appliances become encrusted; depresses the effectiveness of the disinfection of chlorine, thereby causing the need for additional chlorine when $\mathrm{pH}$ is high. Low-pH water will corrode or dissolve metals and other substances [51]. The biological contaminants including bacteria, viruses, and parasites can cause polio, cholera, typhoid fever, dysentery, and infectious hepatitis.

Treatment options for the physicochemical contaminants include aeration and slow sand filtration. The iron and manganese are oxidised during the aeration process, and water is slowly filtered through sand, pathogens are also easily removed. Chlorine tablets were used to disinfect the drilled boreholes in the study area, microbial analysis after the treatment shows the system is effective in eliminating pathogens in the groundwater (Table 5).

\section{Conclusions}

This study focused on the hydrogeological and hydrochemical assessment of groundwater to determine the hydraulic, physicochemical and microbiological properties of the basin granitoids aquifer in the Assin and Breman district of Ghana. The geology is made up of biotite rich granitoids, biotite gneiss, mafic dykes and dolerite intrusives. The productive aquifers are the combination of the thick weathered zone with well fractured bedrock. These zones were delineated 
via surface geophysical methods such as horizontal electrical resistivity profiling (HERP) and vertical electrical sounding (VES) using the Schlumberger array. Sites delineated by the geophysical survey were drilled, developed and sampled for analysis.

Constant pumping rate test was conducted for twenty-five (25) boreholes. Cooper Jacob method was used to estimate transmissivity. Empirical analytical relations for fractured granitic $\left(\mathrm{T}_{\mathrm{FG}}\right)$ and crystalline $\left(\mathrm{T}_{\mathrm{C}}\right)$ aquifer, were used to compare estimated pumping test transmissivity. Hydraulic conductivity was obtained by dividing the transmissivity with the aquifer thickness. The hydraulic conductivity $(\mathrm{K})$ and transmissivity $(\mathrm{T})$ was respectively between $0.02-0.90$ $\mathrm{m}$ /day and $0.36-13.47 \mathrm{~m}^{2} /$ day with mean of $0.24 \mathrm{~m} /$ day and $3.03 \mathrm{~m}^{2} /$ day respectively. Empirical analytical relations for fractured granitic $\left(\mathrm{T}_{\mathrm{FG}}\right)$ and crystalline $\left(\mathrm{T}_{\mathrm{C}}\right)$ aquifer transmissivity respectively ranged between $0.13-13.47 \mathrm{~m}^{2} /$ day and $0.27-5.39 \mathrm{~m}^{2} /$ day with mean of 1.14 and $1.80 \mathrm{~m}^{2} /$ day respectively. Aquifer hydraulic parameters $\mathrm{Q}, \mathrm{K}$ and $\mathrm{T}$ showed a strong positive correlation with $\mathrm{Q} / \mathrm{S}_{\mathrm{w}}$ with $\mathrm{R}$ value $0.8462,0.8738$ and 0.8332 respectively. Whereas aquifer parameters ELV (elevation) and Aquifer (aquifer thickness) showed a moderate positive correlation with SWL (static water level) with $\mathrm{R}$ value 0.5024 and 0.5324 respectively. The $\mathrm{K}$ values indicate a hydrogeological condition of aquiclude with relatively low permeability and medium water bearing capacity. The aquifer transmissivity magnitude is very low to low, groundwater should be used for local water supply with limited and private consumption.

Groundwater samples were taken from six representative boreholes to determine its quality, after which the results were compared with the Ghana Standards Authority (GSA) water quality specification for drinking water (GS 175-1) and World Health Organisation (WHO) guidelines for drinking water quality. All physicochemical parameters were within the permissible limits except for apparent colour, $\mathrm{pH}, \mathrm{Fe}$ and $\mathrm{Mn}$. The groundwater in the area shows dominance order in the cations concentrations of $\mathrm{Ca}^{2+}>\mathrm{Na}^{+}>\mathrm{Mg}^{2+}$ and concentration of anions as $\mathrm{Cl}^{-}>\mathrm{HCO}_{3}^{-}>\mathrm{SO}_{4}^{2-}$. The study area has high $\mathrm{Ca}+\mathrm{Na}+\mathrm{Mg}$ and $\mathrm{HCO}_{3}+\mathrm{Cl}$ relative to $\mathrm{K}$ and $\mathrm{SO}_{4}$ respectively. About $50 \%$ of the analysed water samples has no dominant cation-anion pair. Five water types dominate the study area namely; $\mathrm{Ca}-\mathrm{HCO}_{3}, \mathrm{Na}-\mathrm{Mg}-\mathrm{HCO}_{3}-\mathrm{SO}_{4}, \mathrm{Ca}-\mathrm{SO}_{4}, \mathrm{Na}-\mathrm{Cl}$ and $\mathrm{Mg}-\mathrm{Na}-\mathrm{Cl}$. Gibbs' diagram suggests weathering of rock-forming minerals as the mechanism controlling the groundwater chemistry.

Microbiological parameters Total Coliform, Faecal Coliform, E. coli and Total Heterotrophic Bacterial were above the permissible limits. Both physicochemical and microbiological indicators have been used as contaminant indicators. The contaminants occur naturally because of rock weathering of Iron and Manganese bearing minerals. Microbial contaminants are influenced by both natural and anthropogenic activities, migrating through the weathered and fractured pathways. Groundwater is suitable for drinking after treatment with chlorination, aeration and slow sand filtration methods. 


\section{Conflicts of Interest}

The authors declare no conflicts of interest regarding the publication of this paper.

\section{References}

[1] Aminiyan, M.M., Aminiyan, F.M. and Heydariyan, A. (2016) Study on Hydrochemical Characterization and Annual Changes of Surface Water Quality for Agricultural and Drinking Purposes in Semi-Arid Area. Sustain. Water Resources Management, 2, 473-487. https://doi.org/10.1007/s40899-016-0071-6

[2] Azevedo, E.D.L., Barbosa, J.E.D.L., Viana, L.G., Anacleto, M.J.P., Callisto, M. and Molozzi, J. (2017) Application of a Statistical Model for the Assessment of Environmental Quality in Neotropical Semi-Arid Reservoirs. Environmental Monitoring and Assessment, 189, 65. https://doi.org/10.1007/s10661-016-5723-3

[3] Bahir, M., Moukhayar, R.E., Chamchati, H., Youbi, N., Carreira, P. and Chkir, N. (2014) Recharge and Hydrogeochemical Evolution Groundwater in Semi-Arid Zone (Essaouira Basin, Morocco). Comunicações Geológicas, 101, 651-653.

[4] Ganyaglo, S.Y., Osae, S., Dampare, S.B., Fianko, J.R., Bhuiyan, M.A., Gibrilla, A., Bam, E., Ahialey, E. and Osei, J. (2012) Preliminary Groundwater Quality Assessment in the Central Region of Ghana. Environmental Earth Sciences, 66, 573-587. https://doi.org/10.1007/s12665-011-1266-7

[5] Touhari, F., Meddi, M., Mehaiguene, M., and Razack, M. (2015) Hydrogeochemical Assessment of the Upper Cheliff Groundwater (North West Algeria). Environmental Earth Sciences, 73, 3043-3061. https://doi.org/10.1007/s12665-014-3598-6

[6] Acheampong, S.Y. and Hess, J.W. (1998) Hydrogeologic and Hydrochemical Framework of the Shallow Groundwater System in the Southern Voltaian Sedimentary Basin of Ghana. Hydrogeology Journal, 6, 527-537.

https://doi.org/10.1007/s100400050173

[7] Banoeng-Yakubo, B., Yidana, M.S., Ajayi, J.O., Loh, Y.S. and Asiedu, D.K. (2010) Hydrogeology and Groundwater Resources of Ghana: A Review of the Hydrogeology and Hydrochemistry of Ghana. In: McMann, J.M., Ed., Potable Water and Sanitation, Nova Science Publishers, New York, 115-150.

[8] Ewusi, A. and Kuma, J.S. (2011) Calibration of Shallow Borehole Drilling Sites Using the Electrical Resistivity Imaging Technique in the Granitoids of Central Region, Ghana. Natural Resources Research, 20, 57-63. https://doi.org/10.1007/s11053-010-9129-6

[9] Ewusi, A. and Seidu, J. (2018) Hydrogeology of the Basin Granitoids in the Sekyere South District of Ashanti Region, Ghana. Journal of Geoscience and Environment Protection, 6, 252-263. https://doi.org/10.4236/gep.2018.64015

[10] Saka, D., Akiti, T.T., Osae, S., Appenteng, M.K. and Gibrilla, A. (2013) Hydrogeochemistry and Isotope Studies of Groundwater in the Ga West Municipal Area, Ghana. Applied Water Science, 3, 577-588. https://doi.org/10.1007/s13201-013-0104-3

[11] Guo, H. and Wang, Y. (2005) Geochemical Characteristics of Shallow Groundwater in Da-Tong Basin, Northwestern China. Journal of Geochemical Exploration, 87, 109-120. https://doi.org/10.1016/j.gexplo.2005.08.002

[12] Carrilo-Rivera, J.J., Varsanyi, I., Kovacs, L.O. and Cardona, A. (2007) Tracing Groundwater Flow Systems with Hydrogeochemistry in Contrasting Geological En- 
vironments. Water, Air, \& Soil Pollution, 184, 77-103.

https://doi.org/10.1007/s11270-007-9400-6

[13] Al-Khashman, O.A. (2008) Assessment of the Spring Water Quality in the Shoubak Area, Jordan. Environmentalist, 28, 203-215. https://doi.org/10.1007/s10669-007-9129-1

[14] Sharif, M.U., Davis, R.K., Steele, K.F., Kim, B., Kresse, T.M. and Fazio, J.A. (2008) In-Verse Geochemical Modeling of Groundwater Evolution with Emphasis on Arsenic in the Mississippi River Valley Alluvial Aquifer, Arkansas (USA). Journal of Hydrology, 350, 41-55. https://doi.org/10.1016/j.jhydrol.2007.11.027

[15] Pazand, K. and Fereidoni Sarvestani, J. (2013) Hydrogeochemical Investigation in an Arid Region of Iran (Tabas, Central Iran). Environ. Earth Science, 70, 743-752. https://doi.org/10.1007/s12665-012-2162-5

[16] Pazand, K. (2014) Geochemical and Hydrogeochemical Evolution of Groundwater in Ferdows Area, Northeast of Iran. Environmental Earth Sciences, 71, 685-695. https://doi.org/10.1007/s12665-013-2470-4

[17] Pazand, K., Khosravi, D., Ghaderi, M.R. and Rezvanianzadeh, M.R. (2018) Identification of the Hydrogeochemical Processes and Assessment of Groundwater in a Semi-Arid Region Using Major Ion Chemistry: A Case Study of Ardestan Basin in Central Iran. Groundwater for Sustainable Development, 6, 245-254. https://doi.org/10.1016/j.gsd.2018.01.008

[18] Yang, Q., Li, Z., Ma, H., Wang, L. and Martin, J.D. (2016) Identification of the Hydrogeochemical Processes and Assessment of Groundwater Quality Using Classic Integrated Geochemical Methods in the Southeastern Part of Ordos's Basin, China. Environmental Pollution, 218, 879-888. https://doi.org/10.1016/j.envpol.2016.08.017

[19] Ghana Geological Survey (2009) Geological Map of Ghana-1:1,000,000. Geological Survey Department, Accra.

[20] Dickson, K.B. and Benneh, G. (1988) A New Geography of Ghana. Longman, London.

[21] Assie, K.E. (2008) Lode Gold Mineralisation in the Paleoproterozoic (Birimian) Volcano-Sedimentary Sequence of Afema Gold District, Southeastern Côte d'Ivoire. Journal of African Earth Sciences, 57, 423-430.

[22] Junner, N.R. (1940) Geology of the Gold Coast and Western Togoland (with Revised Geological Map). Gold Coast Geological Survey Bulletin No. 11, 40 p.

[23] Arnould, M. (1961) Étude Géologique des Migmatites et des Granites Précambriens du Nord-est de la Côre d'Ivoire et de la Haute-Volta Méridionale: Cadre Géologique, Classification, Principaux Types. Editions Technip, Paris.

[24] Tempier, P. (1969) Données Récentes sur la Géologie de socle de la Côte d'Ivoire, Annales de I Université d'Abidjan (Côte d' Ivoire), 5, 55-92.

[25] Hirdes, W., Davis, D.W. and Eisenlohr, B.N. (1992) Reassessment of Proterozoic Granitoid Ages in Ghana on the Basis of U/Pb Zircon and Monazite Dating. Precambrian Research, 56, 89-96.

[26] Davis, D.W., Hirdes, W., Schaltegger, U. and Nunoo, E.A. (1994) U-Pb Age Constraints on Deposition and the Provenance of Birimian and Gold-Bearing Tarkwaian Sediments in Ghana, West Africa. Precambrian Research, 67, 89-107. https://doi.org/10.1016/0301-9268(94)90006-X

[27] Gibrilla, A., Akiti, T.T., Osae, S., Adomako, D., Ganyaglo, S.Y., Bam, E.P.K. and Hadisu, A. (2010) Hydrogeochemical and Groundwater Quality Studies in the 
Northern Part of the Densu River Basin of Ghana. Journal of Water Resource and Protection, 2, 1071-1081.

[28] Ganyaglo, S.Y., Banoeng-Yakubo, K.B., Osae, S., Dampare, S.B., Fianko, J.R. and Bhuiyan, M.A.H. (2010) Hydrochemical and Isotopic Characterisation of Groundwater in Eastern Region of Ghana. Journal of Water Resource and Protection, 2, 199-208. https://doi.org/10.4236/jwarp.2010.23022

[29] Davis, S.N. and Turk, L.J. (1964) Optimum Depth of Wells in Crystalline Rocks. Groundwater, 2, 6-11. https://doi.org/10.1111/j.1745-6584.1964.tb01750.x

[30] Gibrilla, A., Akiti, T.T., Osae, S., Adomako, D., Ganyaglo, S.Y., Bam, E.P.K. and Hadisu, A. (2010b) Origin of Dissolve Ions in Groundwaters in the Northern Densu River Basin of Ghana Using Stable Isotopes of $18 \mathrm{O}$ and $2 \mathrm{H}$. Journal of Water Resource and Protection, 2, 1010-1019. https://doi.org/10.4236/jwarp.2010.212121

[31] Buckley, D.K. (1986) Report on Advisory to Water Aid Projects in Ghana. Unpublished Report, British Geological Survey, Hydrogeology Research Group, Wallingford, $56 \mathrm{p}$.

[32] National Research Council (1996) Rock Fractures and Fluid Flow: Contemporary Understanding and Applications. The National Academies Press, Washington DC.

[33] Gibrilla, A., Bam, E.K.P., Adomako, D., Ganyaglo, S., Osae, S., Akiti, T.T., Kebede, S., Achoribo, E., Ahialey, E., Ayanu, G. and Agyeman, E.K. (2011) Application of Water Quality Index (WQI) and Multivariate Analysis for Groundwater Quality Assessment of the Birimian and Cape Coast Granitoid Complex: Densu River Basin of Ghana. Water Quality Exposure and Health, 3, 63-78.

https://doi.org/10.1007/s12403-011-0044-9

[34] Prackley, S. (1984) The 30-Well Project. Internal Report, Catholic Diocese of Accra, Accra, 40 p.

[35] Akiti, T.T. (1986) Environmental Isotope Study of Groundwater in Crystalline Rocks of the Accra Plains. In: 4th Working Meeting on Isotopes in Nature, Proceedings of an Advisory Group Meeting, IAEA, Vienna.

[36] Chitea, F., Georgescu, P. and Loan, E.D. (2011) Geophysical Detection of Marine Intrusion in Black Sea Coastal Areas (Romania) Using VES and ERT Data. Geo Eco Marina, 17, 95-102.

[37] Ward, S.H. (1990) Resistivity and Induced Polarization Methods. Geotechnical and Environmental Geophysics, 1, 147-189. https://doi.org/10.1190/1.9781560802785.ch6

[38] Cooper, H.H. and Jacob, C.E. (1946) A Generalized Graphical Method for Evaluating Formation Constants and Summarizing Well-Field History. Eos, Transactions American Geophysical Union, 27, 526-534. https://doi.org/10.1029/TR027i004p00526

[39] Todd, D.K. (1959) Groundwater Hydrology. John Wiley and Sons, New York.

[40] Mace, R.E. (2001) Estimating Transmissivity Using Specific-Capacity Data. The University of Texas at Austin, Bureau of Economic Geology, Geological Circular 01-2, $44 \mathrm{p}$.

[41] Fabbri, P. (1997) Transmissivity in the Geothermal Euganean Basin: A Geostatistical Analysis. Ground Water, 35, 881-887. https://doi.org/10.1111/j.1745-6584.1997.tb00156.x

[42] Huntley, D., Nommensen, R. and Steffey, D. (1992) The Use of Specific Capacity to Assess Transmissivity in Fractured-Rock Aquifers. Ground Water, 30, 396-402. https://doi.org/10.1111/j.1745-6584.1992.tb02008.x 
[43] Jalludin, M. and Razack, M. (2004) Assessment of Hydraulic Properties of Sedimentary and Volcanic Aquifer Systems under Arid Conditions in the Republic of Djibouti (Horn of Africa). Hydrogeology Journal, 12, 159-170. https://doi.org/10.1007/s10040-003-0312-2

[44] Richard, S.K., Chesnaux, R., Rouleau, A. and Coupe, R.H. (2016) Estimating the Reliability of Aquifer Transmissivity Values Obtained from Specific Capacity Tests: Examples from the Saguenay-Lac-Saint-Jean Aquifers, Canada. Hydrological Sciences Journal, 61, 173-185. https://doi.org/10.1080/02626667.2014.966720

[45] Classen, H.C. (1982) Guidelines and Techniques for Obtaining Water Samples That Accurately Represents the Quality of an Aquifer. Lakewood, US Geological Survey Open File Report 82-1024, 49 p.

[46] Barcelona, M., Gibb, J.P., Helfrich, J.A. and Garske, E.E. (1985) Practical Guide for Groundwater Sampling. Illinois State Water Survey ISWS Contract Report, Champaign, $374 \mathrm{p}$.

[47] Gibbs, R.J. (1970) Mechanisms Controlling World Water Chemistry. Science, 17, 1088-1090. https://doi.org/10.1126/science.170.3962.1088

[48] Hölting, B. and Coldewey, W.G. (2009) Hydrogeologie Einführung in die Allgemeine und Angewandte Hydrogeologie. Spektrum Akademischer Verlag, Heidelberg, 384 p.

[49] Krásný, J. (1992) Classification of Transmissivity Magnitude and Variation. Ground Water, 31, 230-236. https://doi.org/10.1111/j.1745-6584.1993.tb01815.x

[50] Ghana Standards Authority (2009) Water Quality-Specification for Drinking Water. GS 175-1 3rd, Accra.

[51] World Health Organization (2004) Guidelines for Drinking Water Quality. Vol. 1, Recommendations, 3rd Edition, World Health Organization, Geneva.

[52] Schoeller, H. (1962) Les eaux souterraines (The Underground Networks). Mason and Cie, Paris, $642 \mathrm{p}$.

[53] Piper, A.M. (1953) A Graphic Procedure in the Geochemical Interpretation of Water Analysis. U.S. Geol. Survey, Washington DC, Groundwater Note 12, 63 p.

[54] Hem, J.D. (1985) Study and Interpretation of the Chemical Characteristics of Natural Water. Geological Survey Water Supply Paper 2254, Washington DC, 263 p.

[55] Back, W. and Hanshaw, B. (1965) Chemical Geohydrology Advances in Hydroscience. Academic Press, Cambridge, 49-109.

[56] Utom, A.U., Odoh, B.I. and Egboka, B.C. (2013) Assessment of Hydrogeochemical Characteristics of Groundwater Quality in the Vicinity of Okpara Coal and Obwetti Fireclay Mines, near Enugu Town, Nigeria. Applied Water Science, 3, 271-281. https://doi.org/10.1007/s13201-013-0080-7

[57] Lloyd, W.J. and Heathcote, A.J. (1985) Natural Inorganic Chemistry in Relation to Groundwater. Claredon Press, Oxford, $250 \mathrm{p}$.

[58] Amuzu, A.T. (1975) A Survey of the Water Quality of the River Densu. WRRI Technical Report, Accra.

[59] Andah, A.I. (1993) Groundwater Utilization for Small-Scale Irrigation in the Accra Plains: Kponkpo and Ablekuma Pilot Schemes. Water Resources Research Institute (C.S.I.R), Accra.

[60] Ayibotele, N.B. (1985) Development and Management of Groundwater Resources in Ghana-Some Current Problems. Lecture IV, 2nd International Advanced Course on Water Resources Management, Centre for International Studies, Perugia. 
[61] Darko, P.K., Dua, A.A. and Dapaah-Siakwan, S. (2003) Groundwater Assessment: An Element of Integrated Water Resources Management: The Case of Densu River Basin. Technical Report for the Water Resources Commission, Accra.

[62] Kortatsi, B.K. (1994) Groundwater Utilization in Ghana. In: Future Groundwater Resources at Risk, Proceedings of the Helsinki Conference, IAHS Press, Wallingford, IAHS Publ. No. 222, 149-156.

[63] Obuobi, E. and Barry, B. (2010) Groundwater in Sub-Saharan Africa: Implications for Food Security and Livelihoods. Country Status on Groundwater Final Report, IWMI, Ghana.

[64] Pelig-Ba, K.B. (1998) Trace Elements in Groundwater from Some Crystalline Rocks in the Upper Regions of Ghana. Water, Air and Soil Pollution, 103, 71-89. https://doi.org/10.1023/A:1004968109028

[65] Tay, C. and Kortatsi, B.K. (2008) Groundwater Quality Studies: A Case Study of the Densu Basin, Ghana. West African Journal of Applied Ecology, 12, 81-99. 